Review

\title{
Metal Nanoparticle and Quantum Dot Tags for Signal Amplification in Electrochemical Immunosensors for Biomarker Detection
}

\author{
Anton Popov ${ }^{1,2,+}+\mathbb{D}$, Benediktas Brasiunas ${ }^{2,+}$, Asta Kausaite-Minkstimiene ${ }^{1,2}(\mathbb{D})$ and Almira Ramanaviciene ${ }^{1,2, *(D)}$ \\ 1 Department of Immunology, State Research Institute Centre for Innovative Medicine, Santariskiu St. 5, \\ LT-08406 Vilnius, Lithuania; anton.popov@imcentras.lt (A.P.); asta.kausaite@chf.vu.lt (A.K.-M.) \\ 2 NanoTechnas-Center of Nanotechnology and Materials Science, Faculty of Chemistry and Geosciences, \\ Institute of Chemistry, Vilnius University, Naugarduko St. 24, LT-03225 Vilnius, Lithuania; \\ benediktas.brasiunas@chgf.vu.lt \\ * Correspondence: almira.ramanaviciene@chf.vu.lt \\ + Authors contributed equally to this work as first authors.
}

check for

updates

Citation: Popov, A.; Brasiunas, B.; Kausaite-Minkstimiene, A.;

Ramanaviciene, A. Metal

Nanoparticle and Quantum Dot Tags for Signal Amplification in

Electrochemical Immunosensors for Biomarker Detection. Chemosensors 2021, 9, 85. https://doi.org/10.3390/ chemosensors 9040085

Academic Editor: Mehmet Senel

Received: 14 March 2021

Accepted: 15 April 2021

Published: 18 April 2021

Publisher's Note: MDPI stays neutral with regard to jurisdictional claims in published maps and institutional affiliations.

Copyright: (c) 2021 by the authors. Licensee MDPI, Basel, Switzerland. This article is an open access article distributed under the terms and conditions of the Creative Commons Attribution (CC BY) license (https:/ / creativecommons.org/licenses/by/ $4.0 /)$.

\begin{abstract}
With the increasing importance of healthcare and clinical diagnosis, as well as the growing demand for highly sensitive analytical instruments, immunosensors have received considerable attention. In this review, electrochemical immunosensor signal amplification strategies using metal nanoparticles (MNPs) and quantum dots (Qdots) as tags are overviewed, focusing on recent developments in the ultrasensitive detection of biomarkers. MNPs and Qdots can be used separately or in combination with other nanostructures, while performing the function of nanocarriers, electroactive labels, or catalysts. Thus, different functions of MNPs and Qdots as well as recent advances in electrochemical signal amplification are discussed. Additionally, the methods most often used for antibody immobilization on nanoparticles, immunoassay formats, and electrochemical methods for indirect biomarker detection are overviewed.
\end{abstract}

Keywords: metal nanoparticles; gold nanoparticles; quantum dots; electrochemical signal amplifying tags; antibody immobilization; biomarkers; electrochemical immunosensors

\section{Introduction}

There are many different analytical systems, where the specific affinity-based interaction between antigen and antibody is exploited for analyte detection. In the late 1950s, R. S. Yalow and S. A. Berson developed a radioimmunoassay for endogenous plasma insulin detection [1]. After the replacement of the radioactive label by an enzyme, enzymelinked immunoassays [2] and enzyme-linked immunosorbent assays (the gold standard of immunoassays [3]) were introduced and are still very popular worldwide in different fields of application, including clinical medicine [4,5]. Further advances in analytical and bioanalytical chemistry and the increasing need for small, easy to use, portable, well operating in small volume of samples and at the same time sensitive, selective, and highly reproducible systems have encouraged the development of alternative technologies and devices already in use. Thus, a special type of affinity biosensor, so-called immunosensor, was developed. The immunosensor differs from other types of biosensors by the biological recognition element, namely, antibodies (or antigens) are coupled to a signal transducer sensor surface (Figure 1). The physicochemical changes occurring on the signal transducer surface after immunorecognition element interaction with the target analyte and immune complex formation are converted by an electronic system to a measurable analytical signal proportional to the analyte concentration in the sample. Due to the high specificity and affinity of antibodies, the analyte separation step from the mixture of different molecules present in the real sample or the pretreatment of the sample is not required. These outstanding advantages of immunosensors over other analytical techniques open up a wide 
range of applications in a variety of sectors, such as healthcare and clinical diagnosis of biomarkers [6,7], food production and safety [8], the pharmaceutical industry [9], and environmental monitoring [10].

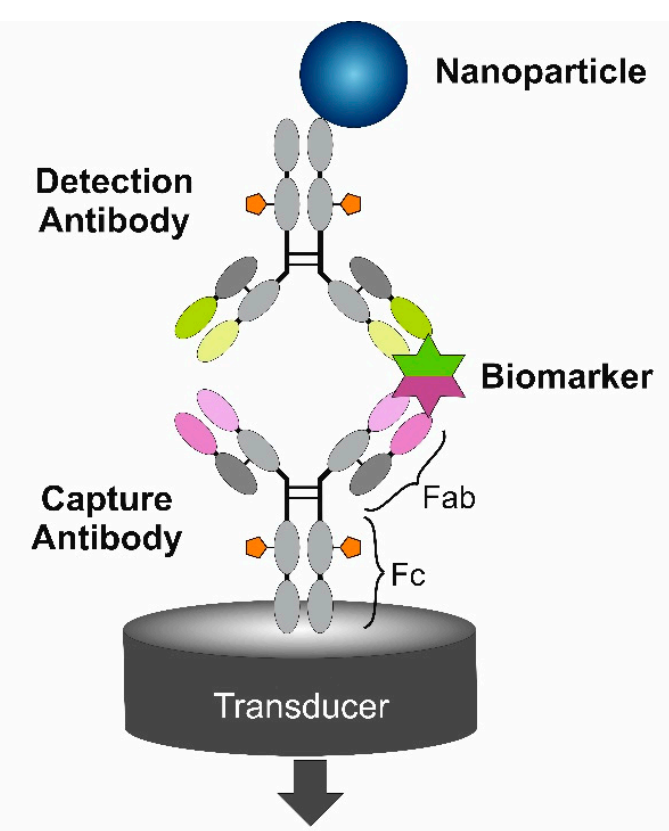

\section{Electrochemical Signal Detection Methods}

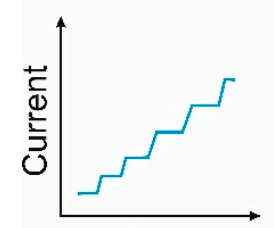

Time

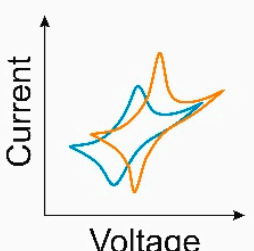

Voltage

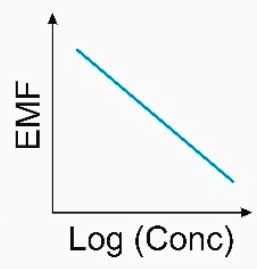

\section{Amperometric Voltammetric Potentiometric}

Figure 1. Schema of electrochemical immunosensors based on nanoparticle tags.

The analytical characteristics of immunosensors depend on many factors. The proper antibody immobilization and site-directed orientation on the sensing surface has a high impact on the performance of the immunosensor [11,12]. Analytes can be detected using different immunoassay formats, mainly direct, indirect, sandwich or competitive. The sensitive detection of analytes by the direct method is desirable; however, sandwich or competitive immunoassay formats provide higher sensitivity. Depending on the type and characteristics of the analyte, either the antibody or the antigen can be immobilized on the sensing surface. Additionally, different analytical signal amplification strategies are applied and the impact of nanotechnology is of crucial importance for future immunosensors. There are two main types of signal amplification strategies using nanomaterials. The first employs nanomaterials for modifying the sensing surface, while the second uses nanomaterials as tags, such as nanocarriers, electroactive and catalytically active labels, or labels for analyte preconcentration. On the back of these factors, the selection of the appropriate signal transducer is of high importance. Depending on the type of transducer, immunosensors can be divided into optical, electrochemical, piezoelectric, magnetic, thermometric, and acoustic immunosensors.

In this review, electrochemical immunosensors based on nanomaterials as signal amplifying tags are overviewed, focusing on recently developed strategies for the ultrasensitive detection of biomarkers. Of all the nanomaterials, zero-dimensional metal nanoparticles (MNPs) and quantum dots (Qdots) were selected. Overviewing different MNPs, more attention is given to gold nanoparticles (AuNPs) due to their wide range 
of advantageous properties, such as chemical stability, excellent biocompatibility, surface chemistry, large surface-to-volume ratio, and easy modification protocols, which are the focus of research and application in electrochemical immunosensors. Another type of powerful nanomaterials well known due to their high quantum yield, stability, and application in optical analytical systems, namely, Qdots, semiconductor nanocrystals, are overviewed as signal amplifying tags in electrochemical immunosensors. The properties of Qdots, such as water solubility, biocompatibility (after appropriate surface modification procedure), catalytic activity, and decomposition reactions upon reduction and oxidation [13,14], were successfully employed in the novel electrochemical immunosensors.

\section{Biomarkers}

According to the World Health Organization's suggested definition, "a biomarker is any substance, structure, or process that can be measured in the body or its products and influence or predict the incidence of outcome or disease" [15]. The US National Cancer Institute indicates that a biomarker is "a biological molecule found in blood, other body fluids, or tissues that is a sign of a normal or abnormal process, or of a condition or disease and can be tested to see how well the body responds to treatment for a disease or condition" [16]. The US National Institutes of Health's Working Group and the Biomarkers Consortium defined a biomarker as "a characteristic that can be objectively measured and quantitatively evaluated as an indicator of a normal biological and pathological process, or pharmacological responses to a therapeutic intervention" [17].

Biomarkers are classified according to different criteria. Depending on the application, they are generally divided into predictive or early detection biomarkers, diagnostic or staging of disease biomarkers, prognostic biomarkers and monitoring biomarkers. An example of a predictive biomarker in prostate cancer is prostate-specific antigen (PSA) or in breast cancer is the expression of the human epidermal growth factor receptor (HER). Glycated hemoglobin is used as a diagnostic biomarker to identify patients with Type 2 diabetes mellitus [18]. Mutations in breast cancer genes 1 and 2 can be used as prognostic biomarkers in the evaluation of women with breast cancer to assess the likelihood of a second breast cancer [19]. Cancer antigen 125 (CA125) is used as a monitoring biomarker in the assessment of disease status in patients with ovarian cancer during and after treatment [20]. Depending on the characteristics of the biomarkers, molecular and imaging biomarkers can be distinguished. Imaging biomarker is a biomarker which is determined by imaging techniques such as computed tomography, positron emission tomography or magnetic resonance imaging [21]. Meanwhile, molecular biomarkers are biomarkers characterized by biophysical properties that allow them to be measured in biological samples [22,23].

\section{Immunoassay Formats Using Nanoparticles as Signal Amplifying Tags}

For the biomarker detection with signal amplification using MNPs and Qdots, two main types of immunoassay are used: sandwich and competitive (Figure 2) [24]. The selected format depends on the biomarker size, the presence of different epitopes, concentration in the real sample, and the complexity of the sample. The mentioned immunoassay formats both do not require sample processing before the analysis, which is very convenient and shortens as well as simplifies the analysis.

The sandwich immunoassay format requires two antibodies (capture and detection) specific for different and non-overlapping epitopes of the biomarker to achieve high sensitivity and selectivity as well as accurate results. Capture antibody immobilized on the electrode surface binds the biomarker and then the biomarker can be detected by the detection antibody (in this case, the detection antibody is labeled with nanoparticles) or after the additional binding of the secondary antibody (in this case, the secondary antibody is labeled with nanoparticles) (Figure 2). There is a direct relationship between the magnitude of the registered analytical signal and the biomarker concentration using the sandwich immunoassay format - the registered signal increases with increasing concentration of biomarkers. 


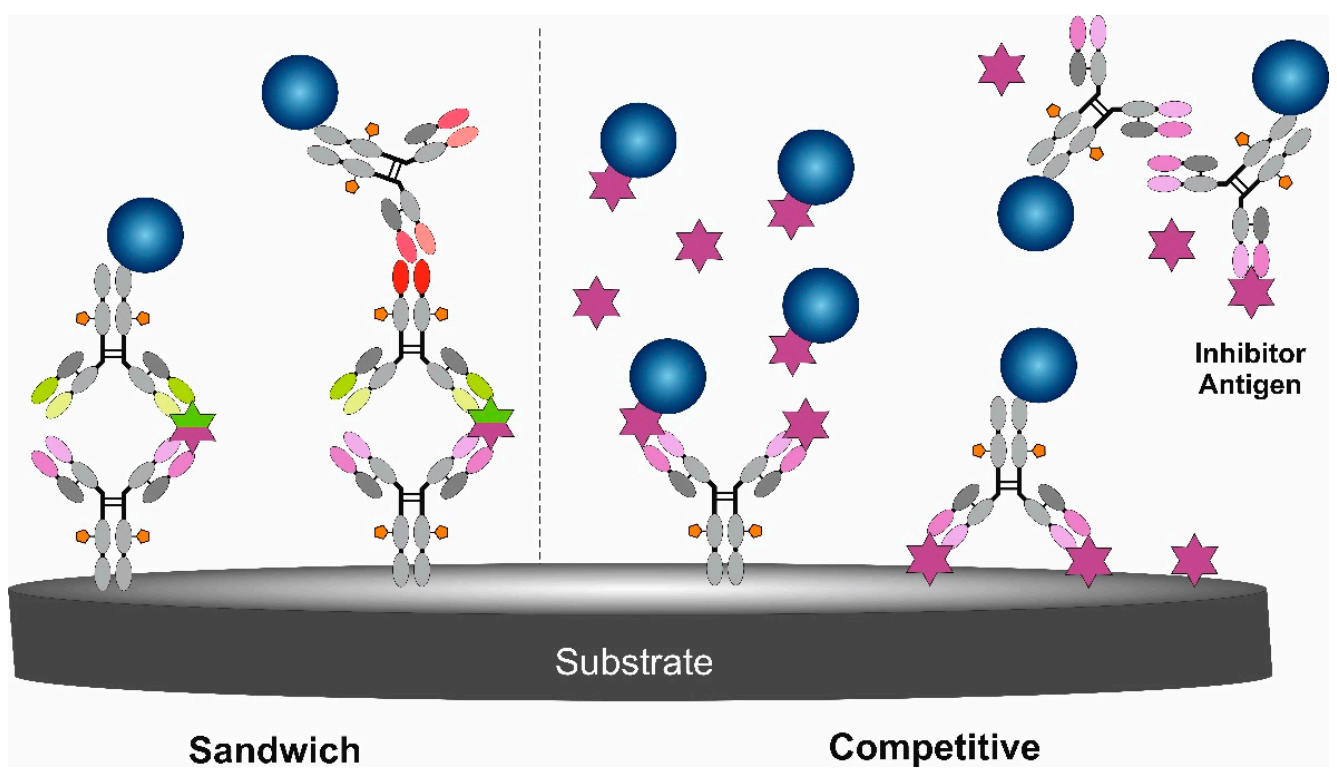

Figure 2. Commonly used immunoassay formats for the detection of biomarkers using nanoparticles as signal amplifying tags.

Competitive/inhibition immunoassay is less sensitive to sample dilution and sample matrix effects in comparison to the sandwich format [24]. Additionally, less variability between two equal samples and assays is specified [25]. The competitive format can be selected for biomarker detection in such cases when only one specific antibody is available or the biomarker is so small that it cannot be bound by two antibodies. There are a few competition options for biomarker detection. When a surface premodified with antibodies is applied in analysis, the biomarker to be determined competes with the reference biomarker labeled with nanoparticles (known and constant concentration) for the free antigen binding sites. A more complex competitive format is performed when antibodies labeled with nanoparticles compete with the biomarker present in the sample and the reference biomarker immobilized on the surface. Only free (not-inhibited) antibodies labeled with metal nanoparticles can interact with the reference biomarker immobilized on the surface. In this case, the biomarker concentration in the sample inversely correlates with the magnitude of the registered signal-the registered signal increases with decreasing concentration of the biomarker.

\section{Methods Used for the Modification of MNPs and Qdots by Antibodies}

As the purpose of this review is to discuss the performance of immunosensors using nanoparticles as signal amplifying tags, the main methods used for the modification of MNPs and Qdots will be presented. Additionally, these methods might be applied as a reference for antibody immobilization on the electrode surface. The methods used for antibody immobilization might be grouped such as (i) covalent or non-covalent [26], (ii) ensuring random or site-directed antibody orientation [11], (iii) using native antibodies or their reduced fragments [12] (Figure 3). The ability of an immobilized antibody to bind the target biomarker depends on antibody Fab fragment accessibility (orientation on the surface) and the remaining biological activity. Immunosensor performance is based on a specific affinity-based (non-covalent) interaction between the antibody-antigen binding site and the epitope present in the biomarker structure. The selection of the best method also depends on the material of the nanoparticle, surface properties, biocompatibility, and particle size. Since the specific interaction between the antibody and the biomarker as well as the magnitude of the registered signal depend on the selected antibody immobilization method, it is obvious that this step is of crucial importance for developing sensitive immunosensors. Additionally, the optimal concentration of antibodies should be chosen for each individual case [27] before applying MNP-antibody conjugates in immunosensor design. 


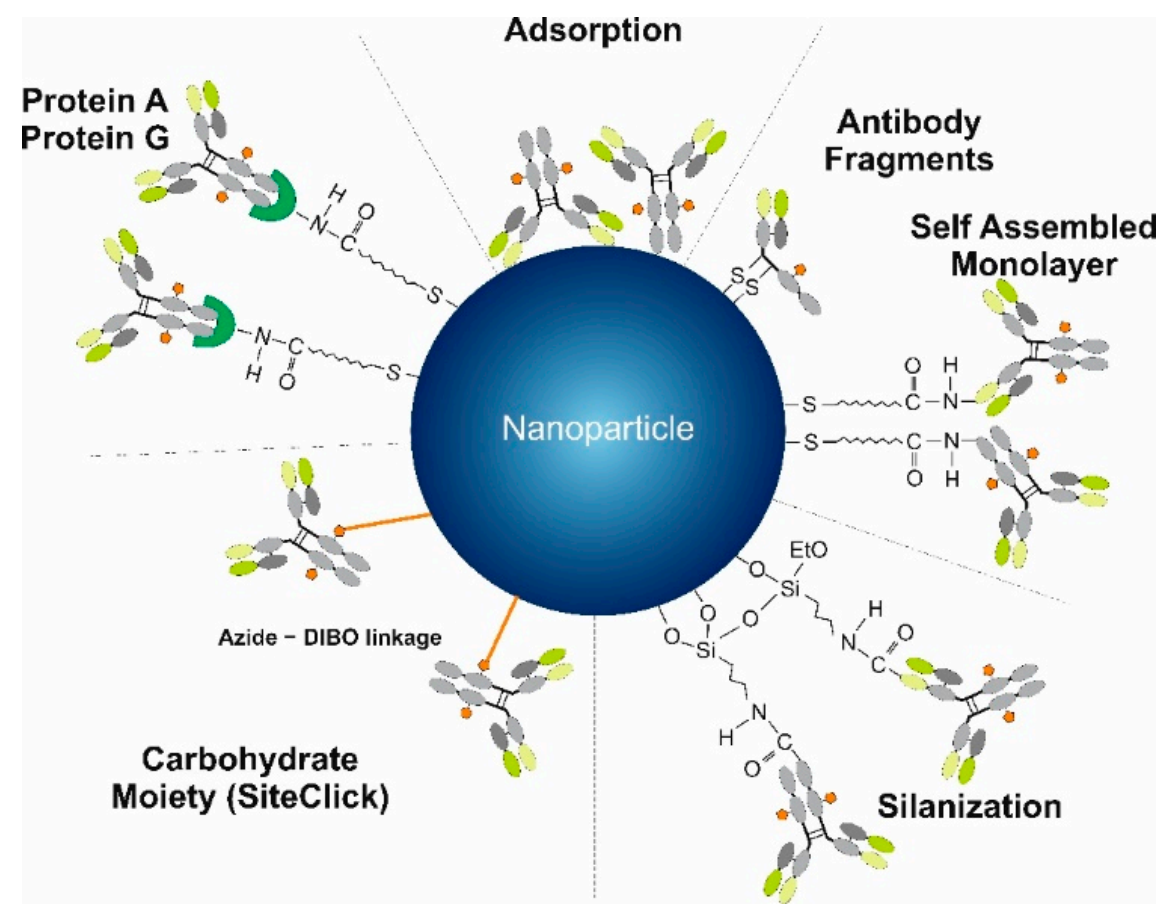

Figure 3. Schematic representation of different methods for antibody immobilization on a nanoparticle.

Noble MNPs (Au, Ag, Pt, Pd), especially AuNPs, can be easily synthesized of different sizes and shapes in aqueous solutions using chemical reductors and metal precursors (bottom-up strategy) [28]; however, nanoparticles without residual toxic compounds can also be synthetized by laser ablation (top-down strategy) in aqueous media [29]. MNPs can be positively or negatively charged. Most often the simple antibody adsorption (due to electrostatic, van der Waals, and hydrophobic interactions, hydrogen bonding) on MNPs is used. Usually, a random orientation of antibodies on the nanoparticle surface is obtained. However, the orientation of antibodies can be regulated by changing the $\mathrm{pH}$ of the solution, thus controlling the surface charge distribution of the antibody and affecting the electrostatic interaction with negatively charged AuNPs. It was shown that antigen binding site accessibility to the biomarker increased by decreasing the $\mathrm{pH}$ of the solution from 8.5 to 7.5 [30]. Despite the drawbacks of the adsorption method, such as low antibody surface concentration, random orientation, partial denaturation in close contact with the metal, and desorption from the surface due to weak bonds, this method is used for MNP modification and is applied for immunosensor development due to its simplicity and easy procedure. Antibodies with thiol groups present in their structure or reduced antibody fragments maintaining native thiol groups are immobilized on the noble metal surface via chemisorption, forming a noble metal-thiolate bond. Reduced antibody fragments ensure site-directed orientation of antibody's antigen binding sites on the plane surface and MNPs [31,32].

Covalent antibody immobilization on MNPs using self-assembled monolayers (SAMs, $\mathrm{n}$-carbon atom alkyl chains with certain functional groups) is another commonly used method that does not ensure site-directed antibody immobilization. The modification of noble MNPs with SAMs occurs due to thiol head group presence in their structure binding to the surface of MNPs via chemisorption. After that, different functional groups generated on the surface (mainly carboxyl or amine) are directed to the solution and are used for the covalent antibody immobilization. The length of the chain regulates the distance from the antibody to the surface and the mobility on the MNPs. Very often 11mercaptoundecanoic acid SAM is used for covalent antibody immobilization after carboxyl group activation with a mixture of 1-ethyl-3-(3-diaminopropyl)carbodiimide hydrochloride and N-hydroxysuccinimide (EDC/NHS coupling reaction) [32,33]. Formed functionally active NHS-ester interacts with antibody amine groups and a stable amide bond is formed. 
The same protocol might be applied for Qdots with carboxyl groups on their surface [34]. Additionally, chemical linkers (glutaraldehyde, N, N'-carbonyldiimidazole) can also be applied for covalent antibody immobilization on Qdots [35]. SAMs with silane head groups, usually amino silanes, are applied for the metal oxide nanoparticle surface functionalization for further covalent antibody immobilization [36]. Alkyl silanes with amines, aldehydes, thiols, or carboxylic functional groups can be successfully used for covalent antibody immobilization after functional group activation or via cross-linking. Despite the resulting random antibody immobilization on the nanoparticle surface, well-operating electrochemical immunosensors based on this antibody immobilization method were developed [37]. The covalent antibody immobilization via SAMs is well known and is quite simple, thus a stable biolayer is applicable for repeated biomarker detection using a regeneration step. The main drawback of this method is random antibody orientation, which can reduce the sensitivity of immunosensors [26].

Site-directed antibody immobilization might be achieved due to the affinity interaction between bacterial proteins $\mathrm{G}$ or $\mathrm{A}$ and the antibody Fc region. This favorable method of antibody immobilization on MNPs significantly improves the antibody-biomarker binding ratio due to antigen binding site accessibility and decreased steric hindrance $[11,26]$. The immobilization of the antibody using protein $\mathrm{G}$ or A ensures site-directed orientation. However, for repeated biomarker detection by an immunosensor, cross-linking of the antibody with protein $G$, which is covalently immobilized to the surface, is required [38]. Affinity interaction between biotinylated antibody and avidin or streptavidin immobilized on the surface is a widely used method for MNPs modification with antibodies, but usually this method does not ensure site-directed orientation of antibodies. The main advantage of this antibody immobilization method is a strong non-covalent interaction between biotin and avidin $\left(\mathrm{K}_{\mathrm{d}} \sim 10^{-15} \mathrm{M}^{-1}\right)$ or streptavidin $\left(\mathrm{K}_{\mathrm{d}} \sim 4 \times 10^{-14} \mathrm{M}^{-1}\right)$ and the resistance of this complex to break down at high temperature, extreme $\mathrm{pH}$ and in the presence of a high concentration of chemical agents [39,40]. Additionally, the avidin/streptavidin ability to interact with four biotin molecules ensures high antibody loading on the surface of MNPs.

Branched oligosaccharides present in the $\mathrm{Fc}$ fragment of the antibody $\left(\mathrm{CH}_{2}\right.$ domain) can be successfully applied for the site-directed antibody immobilization on nanoparticles. Oxidized immunoglobulin $\mathrm{G}(\mathrm{IgG})$ class antibodies can be immobilized on the surface of MNPs premodified with amines, hydrazines, hydrazides, and semicarbazides [41,42]. There are commercially available kits (Site-Click ${ }^{\mathrm{TM}}$ Antibody Labeling Kits) for antibody labeling with Qdots via a modified antibody carbohydrate moiety present in the Fc fragment [43], unlike the conventional amine-thiol crosslinker method. Although no oxidizing or reducing agents are required, the preparation of the conjugate is a multistep process with a few preconcentration, modification (enzymes are used), and separation steps. It is easy to lose an antibody during the conjugation procedure. Additionally, a limited amount of Qdots per $1 \mathrm{M}$ of IgG was mentioned as one of the disadvantages of this method [34].

\section{Electrochemical Immunosensors}

Electrochemical immunosensors quantitatively measure an electrical signal generated during a specific antigen and antibody interaction. Depending upon the nature of the electrochemical changes detected during the immunorecognition events, amperometric, voltammetric, potentiometric, conductometric, and impedimetric immunosensors can be distinguished. Electrochemical immunosensors have unique properties such as high sensitivity, which is important for the detection of biomarkers as their concentrations are usually very low, short response time, and high selectivity. In addition, they are characterized by simplicity of fabrication, low cost, relatively simple instrumentation, the possibility of being portable and small in size, suitability for in situ or automated detection of an analyte, as well as adaptability to multiplexing [44]. In addition, they are ideal for the analysis of opaque and optically dense samples [45]. Due to these properties, they are increasingly used in clinical analysis and are becoming a promising alternative to existing laboratory methods [45]. 


\subsection{Amperometric Immunosensors}

Amperometric immunosensors are one of the most widely used electrochemical immunosensors [6]. They have been successfully applied to detect many biomarkers, such as carcinoembryonic antigen (CEA) [46], human epididymis protein 4 (HE4) [47], human immunoglobulin G [48] and many others. The amperometric technique is very simple to use, which has the potential for miniaturization and portability. It is based on the measurement of the current resulting from the oxidation or reduction of an electroactive material at the surface of an indicator electrode (otherwise known as a working electrode) as a function of time at a constant potential. In addition to the indicator electrode, the amperometric electrochemical cell consists of reference and auxiliary electrodes. The reference electrode has a constant potential and the potential applied to the indicator electrode is controlled with respect to the reference. Meanwhile, the auxiliary electrode completes the electrical circuit and helps to measure the current flow. The simplest way to design an amperometric immunoassay is direct antibody-antigen interaction. However, most antibodies and antigens are not electrochemically active and therefore their interaction cannot generate an amperometric response. This problem is often solved using additional reversible redox-active substances, called redox probes, whose oxidation or reduction at the indicator electrode surface creates a current signal. The insulating immune complex formed on the working electrode surface during antibody and antigen interaction acts as a kinetic barrier to mass and electron transfer between the electrode and the redox probe. Therefore, when the antigen is present in a solution, a decrease in the current response is observed. At identical redox probe concentrations, the current response obtained is related to the antigen concentration [48]. Soluble redox probes can affect the bioactivity of antibodies or antigens by denaturing them and therefore affect the detection and regeneration of immunosensors [49]. To overcome this drawback, redox-active substances are integrated on a working electrode surface, thus eliminating their direct contact with biomolecules. Another type of amperometric immunosensors are immunosensors that utilize peroxidase-like electroactive materials that have high catalytic activity towards the electroreduction of hydrogen peroxide. The immune complex formed during the antibody-antigen interaction causes both electron transfer resistance and steric resistance to hydrogen peroxide, which reduces the current response [50]. Therefore, although amperometric immunosensors based on the label-free detection format have a short response time, are highly compatible, and repeatable, the use of various indirect detection formats applying electrochemically active or enzymatic labels conjugated with a detection antibody or competitive antigen is often required to achieve an amperometric response [6]. The most commonly used enzymatic labels are horseradish peroxidase (HRP), alkaline phosphatase, glucose oxidase, glucose-6-phosphate dehydrogenase, and laccase. The amperometric enzyme-linked immunoassay format is very popular and commonly used in laboratory practice for the detection of both antigens and antibodies. After the addition of a suitable substrate, an electrochemically active product is formed during the enzymatic reaction. Its oxidation or reduction at the indicator electrode surface generates a current signal that is proportional to the concentration of an analyte [51]. Particular attention is currently focused on electrochemically active labels such as noble metals, metal oxide nanoparticles or Qdots. These materials allow the drastic improvement of the analytical characteristics of amperometric immunosensors and also are very promising in multi-analyte assays, which have many advantages over single-analyte assays, such as the cost of a single test and convenience [52].

\subsection{Voltammetric Immunosensors}

A three-electrode electrochemical cell is also used for voltammetric measurements, as well as for amperometric. However, unlike in amperometry, in voltammetry the potential is scanned over a range of potentials and the current resulting from the oxidation or reduction of an electroactive material is measured as a function of the applied potential. Due to the variable potential, voltammetric immunosensors, in addition to properties such as high 
sensitivity and selectivity and short response time, have the ability to simultaneously and quantitatively detect multiple analytes. As three parameters can be controlled in voltammetry: how the potential is changed, how the current is measured, and whether the solution is stirred, there are many different voltammetry techniques that differ in their capabilities. Cyclic voltammetry (CV), linear sweep voltammetry (LSV), differential pulse voltammetry (DPV), square wave voltammetry (SWV), and stripping voltammetry (SV) are the most widely used in the development of immunosensors. Of the techniques mentioned, DPV and SWV are particularly commonly used due to their high sensitivity [53,54]. In addition, due to the narrow peaks in a voltammogram, DPV is a particularly suitable technique for the simultaneous determination of several biomarkers. As a result, false negatives and false positives in clinical diagnoses, more prone to occur when measuring a single molecule, can be minimized [52]. SV, which consists of three related techniques: anodic stripping voltammetry (ASV), cathodic stripping voltammetry and adsorptive stripping voltammetry, is particularly sensitive due to the concentration of an analyte or electroactive label when it is transferred from a larger volume of the solution to a smaller volume near the working electrode. Due to this procedure, the detection limits are much lower than other voltammetric techniques. Voltammetric immunoassay can be performed by direct as well as a variety of indirect formats that were already described for amperometric immunosensors. Among the different types of electrochemical immunosensors, voltammetric immunosensors are very popular and numerous immunosensors for cystatin C [55], Cytokeratin 19 fragment 21-1 [56], CEA [57], C-reactive protein [37] and other biomarkers have been reported over the past decade.

\subsection{Potentiometric Immunosensors}

Potentiometric immunosensors, whose principle of operation is based on the measurement of the potential difference between an indicator electrode and a reference electrode when a zero or insignificant amount of current flows through the cell, have great potential in clinical immunoassays. According to the Nernst equation, the measured potential difference is proportional to the logarithm of concentration. Potentiometric immunoassay can also be performed by direct as well as by a variety of indirect formats. When a potentiometric immunoassay is performed in a direct format, the change in the recorded potential difference depends on the change in the working electrode potential caused by the antibody-antigen interaction. All proteins are polyelectrolytes and have a positive or a negative electrical charge except for their isoelectric point. When an antibody-antigen interaction occurs, the electrical charge of the resulting immune complex differs from the electrical charge of the immobilized antibody. This interaction causes a change in the surface charge of the indicator electrode, resulting in a change in the registered potential difference. The detection is based on the change in the potentiometric signal before and after the antigen-antibody reaction. An example of a potentiometric immunosensor operating in this format is the IgG immunosensor that was proposed by Feng and co-workers [58]. Despite the simplicity, one of the main disadvantages of this type of potentiometric immunoassay format is a small change in potential difference resulting from the antibody-antigen interaction. Attempts have been made to increase the performance by increasing the amount of immobilized antibodies and maintaining their immunoactivity $[59,60]$. Nevertheless, direct detection format-based potentiometric immunosensors are often not sensitive and reliable enough [61]. For this reason, the much more commonly used detection format is the potentiometric enzyme-linked immunoassay [62]. The detection of the product obtained by an enzymatic reaction makes it possible to amplify the potentiometric signal corresponding to the immunorecognition event. Potentiometric enzyme-linked immunoassays also have several drawbacks, such as sensitivity to assay conditions at the potentiometric signal generation stage and the instability of enzymes during storage and use. The use of nanomaterials such as noble metal nanoparticles [63] or Qdots [64] as label and ion-selective electrodes avoids these drawbacks and provides new ways to improve the performance of potentiometric immunosensors. 


\subsection{Photoelectrochemical Immunosensors}

Photoelectrochemical (PEC) immunoassay is a newly developed technique, but in recent years it has attracted a great deal of interest from scientists due to its low cost, short response time, high sensitivity, and portable and small PEC devices [65]. The PEC method evolved from electrochemistry, but it differs from traditional electrochemical methods [66]. In addition, due to the lower background signal, the PEC technique has the potential to be more sensitive than conventional electrochemical methods $[67,68]$. PEC immunoassay converts the immunobinding event into a detectable electrical signal. The principle of PEC immunosensors operation is based on the generation of an electrical signal resulting from the photoelectric conversion of photoactive materials, usually Qdots. PEC immunosensors could be classified into two main groups: potentiometric and amperometric. The most common are amperometric PEC immunosensors, which have been developed rapidly over the past decade. The PEC cell consists of a light-harvesting semiconductor indicator electrode, a counter electrode and a reference electrode. The indicator electrode is initially used for the immobilization of the capture antibody, followed by immunoassay development with different detection formats and signaling strategies. When a photoactive material is illuminated by light with energy higher than that of their band gap, the light excites electron transitions from the valence band to the conduction band, forming electronhole pairs. The migration of photogenerated charge carriers causes a photocurrent signal, which is proportional to the concentration of an analyte. Depending on the change in photocurrent before and after the interaction with an analyte, PEC immunosensors can be divided into signal-on and signal-off methods. One of the most commonly used signal-on methods is the sandwich-type immunoassay format, in which the antigen is sandwiched between the immobilized captured antibody and the detection antibody. Photoreactive Qdots, such as CdS, CdTe, and CdSe, are most commonly used $[69,70]$. The disadvantage of signal-off methods is that they suffer from non-specific adsorption of other biological components present with the analyte in the test sample. This leads to erroneously recorded immunosensor signals, resulting in an inaccurate analysis. Nevertheless, a number of PEC immunosensors of this type have also been reported for the analysis of biomarkers [71,72].

\section{MNP and Qdot Tags for Electrochemical Signal Amplification}

Nanomaterials, including MNPs and Qdots, fulfill various roles in the design of highly sensitive electrochemical immunosensors. The deposition of nanoparticles on the surface of the working electrode permits the enhancement in the surface area, leading to increased molecule loading capacity. Additionally, the deposited nanomaterials could lead to electrical signal amplification due to their unique properties. For instance, the involvement of AuNPs due to high AuNP electrical conductivity accelerates electron transfer to the electrode during reduction-oxidation reactions. However, in this work we focus on the application of MNPs and Qdots as tags for signal amplification in the design of electrochemical immunosensors. MNPs and Qdots can be used separately or in combination with other nanostructures, while the performed functions can be divided as follows (Figure 4):

- Nanocarriers-transport numerous molecules close to the electrode.

- Electroactive labels for biomarker detection.

- Catalytically active labels.

A comprehensive review of the literature about the principles of MNPs and Qdots' application as tags for signal amplification in the electrochemical immunosensors developed for the sensitive detection of biomarkers is provided in the following sections. More detailed information about the analytical characteristics of the developed immunosensors, such as limit of detection (LOD) and linear range, as well as type and size of nanoparticles and electrochemical methods used for the biomarker detection in real samples, is summarized in Table 1, grouping information depending on the function of MNPs and Qdots. 


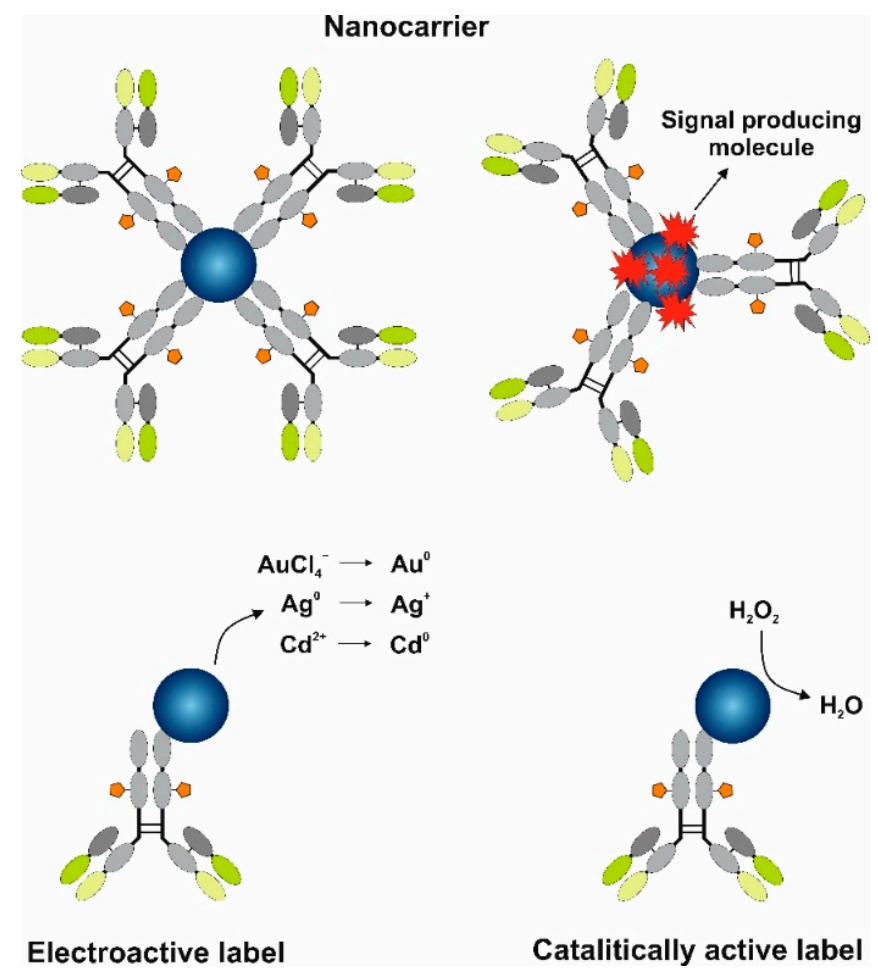

Figure 4. The main functions of metal nanoparticle and quantum dot tags for electrochemical immunosensor signal amplification.

Table 1. The summary of electrochemical immunosensors which employ MNP and Qdot tags for analytical signal amplification.

\begin{tabular}{|c|c|c|c|c|c|c|c|}
\hline & Size (nm) & Technique(s) & Biomarker & $\begin{array}{l}\text { Linear Range } \\
\left(\text { (ng } \cdot \mathrm{mL}^{-1}\right)\end{array}$ & $\begin{array}{c}\text { LOD } \\
\left(\mathrm{pg} \cdot \mathrm{mL}^{-1}\right)\end{array}$ & Real Sample & Reference \\
\hline \multicolumn{8}{|c|}{ Nanocarriers } \\
\hline $\begin{array}{c}\text { AuNPs } \\
\text { (MSNP-Thi-Au) }\end{array}$ & $\begin{array}{c}80(\mathrm{MSN}) \\
5(\mathrm{AuNPs})\end{array}$ & DPV & PSA & $10^{-3}-5$ & 0.31 & Serum & [73] \\
\hline Mesoporous $\mathrm{Fe}_{3} \mathrm{O}_{4}$ & 25 & $\mathrm{CA}$ & cTnI & $10^{-3}-100$ & 0.39 & Serum & [74] \\
\hline $\mathrm{Ni} / \mathrm{C} @ \mathrm{SiO}_{2}$ & 300 & DPV & CEA & $6 \times 10^{-3}-12$ & 1.56 & Serum & [75] \\
\hline AuNPs & 18 & DPV & CA-125 & 20-100 U & $3.4 \mathrm{U}$ & Serum & [76] \\
\hline AuNPs/Thi/MWCNT & 15 (AuNPs) & DPV & CYFRA21-1 & $0.1-150$ & 43 & Serum & [56] \\
\hline AuNPs & 30 & PT & PSA & $0.05-20$ & 13.6 & Serum & [63] \\
\hline NC-AuNPs & $\begin{array}{c}30 \\
\text { (NC-AuNPs) } \\
7.5 \text { (AuNPs) }\end{array}$ & DPV & ALV-J & $\begin{array}{l}120-10^{4} \\
\text { TCID }_{50}\end{array}$ & $95 \mathrm{TCID}_{50}$ & - & [77] \\
\hline $\mathrm{MSNP}-\mathrm{Fe}_{3} \mathrm{O}_{4}$ & $\begin{array}{c}100(\mathrm{MSN}) \\
8\left(\mathrm{Fe}_{3} \mathrm{O}_{4}\right) \\
29\end{array}$ & $\mathrm{CV}$ & AFP & $0.01-25$ & 4 & Serum & [78] \\
\hline $\mathrm{Fe}_{3} \mathrm{O}_{4} / \mathrm{AuNPs}$ & $\begin{array}{c}\left(\mathrm{Fe}_{3} \mathrm{O}_{4} / \mathrm{AuNPs}\right) \\
12 \text { (AuNPs) }\end{array}$ & DPV & CEA & $5 \times 10^{-3}-50$ & 1 & Serum & [79] \\
\hline \multicolumn{8}{|c|}{ Electroactive labels } \\
\hline AuNPs & 13 & DPV & Mtb & $\begin{array}{c}5 \times 10^{3}-5 \times \\
10^{5}\end{array}$ & 330 & Urine & [80] \\
\hline AuNPs & 20 & DPV & hMMP9 & $0.18-23$ & 60 & Plasma & [81] \\
\hline $\mathrm{Cu} @ \mathrm{TiO}_{2}$ & 250 & $\begin{array}{l}\text { SWV } \\
\text { CA }\end{array}$ & $\operatorname{IgG}$ & $\begin{array}{l}10^{-4}-100 \\
10^{-5}-100\end{array}$ & $\begin{array}{c}0.052 \\
4.3 \times 10^{-3}\end{array}$ & Serum & [82] \\
\hline $\begin{array}{l}\text { TiNPs-Zn } \\
\text { TiNPs-Cd }\end{array}$ & 50 (TiNPs) & SWV & $\begin{array}{l}\text { cTnI } \\
\text { FABP }\end{array}$ & $5 \times 10^{-5}-50$ & $\begin{array}{c}10^{-3} \\
3 \times 10^{-3}\end{array}$ & Serum & [83] \\
\hline PbS Qdots & - & SP & HER2 & $1-100$ & 280 & Serum & [84] \\
\hline CdTe:Ni Qdots & - & DPV & PSA & $10^{-3}-100$ & 0.45 & Serum & [85] \\
\hline CdS Qdots & - & DPV & anti-tTG IgA & 40-100 U & $2.2 \mathrm{U}$ & Serum & [86] \\
\hline CdS QDots & - & CA & AFP & $0.1-500$ & 10 & Serum & [87] \\
\hline$\widehat{\mathrm{d} S e}$ & - & PT & Mouse IgG & $0.15-4.0 \mathrm{pM}$ & $10 \mathrm{fM}$ & - & [64] \\
\hline $\mathrm{CdS}$ & 4 & PEC & S100B & $0.25-10$ & 0.15 & Serum & [70] \\
\hline
\end{tabular}


Table 1. Cont

\begin{tabular}{|c|c|c|c|c|c|c|c|}
\hline & Size (nm) & Technique(s) & Biomarker & $\begin{array}{l}\text { Linear Range } \\
\left(\mathrm{ng} \cdot \mathrm{mL}^{-1}\right)\end{array}$ & $\begin{array}{c}\text { LOD } \\
\left(\mathrm{pg} \cdot \mathrm{mL}^{-1}\right)\end{array}$ & Real Sample & Reference \\
\hline $\mathrm{Au} @ \mathrm{Pt}-\mathrm{MoSe}_{2}$ & $\begin{array}{c}45 \times 16(\mathrm{Au}) \\
80 \times 58 \\
(\mathrm{Au} @ \mathrm{Pt})\end{array}$ & CA & AFP & $10^{-5}-200$ & $3.3 \times 10^{-3}$ & Serum & [88] \\
\hline PS@PDA-AgNPs & 200 & LSV & IL-6 & $10^{-4}-100$ & 0.059 & Serum & [89] \\
\hline Graphene/AgNPs & - & SW ASV & $\operatorname{IgE}$ & $10-1000$ & $3.6 \times 10^{3}$ & - & [90] \\
\hline Au@PAMAM-C 60 & 100 & LSV & AFP & $10^{-4}-10$ & 0.03 & Serum & [91] \\
\hline $\mathrm{Ag} @ \mathrm{CeO}_{2}-\mathrm{Au}$ & $\begin{array}{c}50-100 \\
\left(\mathrm{Ag} @ \mathrm{CeO}_{2}\right)\end{array}$ & $\mathrm{CV}$ & CEA & $10^{-4}-5$ & $3.2 \times 10^{-3}$ & Serum & [92] \\
\hline AuNPs/MB/MSNP & $80(\mathrm{MSN})$ & ASV & Gal-3 & $5 \times 10^{-7}-500$ & $1.7 \times 10^{-4}$ & Serum & [93] \\
\hline AuNPs-PDC-GOx & - & ASV & PCT & $5 \times 10^{-7}-500$ & $4 \times 10^{-5}$ & Serum & [94] \\
\hline AuNPs & 13 & ASV & $\begin{array}{l}\text { IgG } \\
\text { PSA }\end{array}$ & $\begin{array}{c}4 \times 10^{-7}-400 \\
1.8 \times 10^{-7}-450\end{array}$ & $\begin{array}{c}3 \times 10^{-4} \\
10^{-4}\end{array}$ & Serum & [95] \\
\hline $\mathrm{AuNPs}-\mathrm{Fe}_{3} \mathrm{O}_{4}$ & $\begin{array}{c}30\left(\mathrm{Fe}_{3} \mathrm{O}_{4}\right) \\
25 \text { (AuNPs) }\end{array}$ & DPV & HER2 & $5 \times 10^{-4}-50$ & 0.02 & Serum & [96] \\
\hline $\begin{array}{c}\mathrm{AuNPs} / \mathrm{Au} / \text { spiky } \\
\mathrm{Au} / \mathrm{Ag}\end{array}$ & 250 & LSV & PSA & $\begin{array}{c}1.9 \times \\
10^{-3}-0.125 \\
0.125-10\end{array}$ & 1.2 & - & [97] \\
\hline AuNPs & 13 & SWE & PDGF & $5 \times 10^{-3}-10$ & 2 & Serum & [98] \\
\hline $\mathrm{Ag} @ \mathrm{Au}$ & - & LSV & CEA & $0.1-120$ & 55 & - & [99] \\
\hline \multicolumn{8}{|c|}{ Catalytically active labels } \\
\hline $\mathrm{CoSnS}_{\mathrm{x}}-\mathrm{Pd}$ & $200-600$ & $\mathrm{CA}$ & NT-pro BNP & $10^{-4}-50$ & 0.0315 & Serum & [100] \\
\hline $\mathrm{Cu}_{3}\left(\mathrm{PO}_{4}\right)_{2}$ & 200 & SWV & CRP & $5 \times 10^{-4}-1$ & 0.13 & Serum & [101] \\
\hline $\mathrm{PtPd}-\mathrm{Fe}_{3} \mathrm{O}_{4}$ & 10 & CA & $\begin{array}{l}\text { CA72-4 } \\
\text { CEA }\end{array}$ & $\begin{array}{l}10^{-3}-10 \mathrm{U} \\
0.05-20 \mathrm{U}\end{array}$ & $\begin{array}{c}0.3 \mathrm{mU} \\
2 \mathrm{mU}\end{array}$ & Serum & [102] \\
\hline Mesoporous Pt NPs & 30 & DPV & $\begin{array}{l}\text { CA-125 } \\
\text { CA-153 }\end{array}$ & $\begin{array}{c}8 \times 10^{-3}-24 \mathrm{U} \\
0.02-20\end{array}$ & $\begin{array}{c}1 \mathrm{mU} \\
7\end{array}$ & Serum & [103] \\
\hline $\begin{array}{c}\text { PdNi NPs/ } \\
\text { graphene nanoribbon }\end{array}$ & 10 (PdNi NPs) & CA & AFP & $10^{-4}-16$ & 0.03 & Serum & [104] \\
\hline $\begin{array}{c}\mathrm{Au} @ \mathrm{Pd} \\
\mathrm{NDs} / \mathrm{NH}_{2}-\mathrm{MoO}_{2} \mathrm{NSs}\end{array}$ & $\begin{array}{c}20 \text { (Au@Pd } \\
\text { NDs) }\end{array}$ & CA & HBsAg & $10^{-5}-100$ & $3.3 \times 10^{-3}$ & Serum & [105] \\
\hline $\mathrm{Zn}_{2} \mathrm{SiO}_{4}-\mathrm{PdNPs}$ & $\begin{array}{c}100-200 \\
\left(\mathrm{Zn}_{2} \mathrm{SiO}_{4}\right)\end{array}$ & SWV & Insulin & $10^{-4}-50$ & $2.5 \times 10^{-4}$ & Serum & [106] \\
\hline
\end{tabular}

Abbreviations: AFP: Alpha fetoprotein, ALV-J: Avian leukosis virus subgroup J, anti-tTG IgA: anti-tissue transglutaminase antibody, CA: chronoamperometry, CA-125: carcinoma antigen 125, CA-153: carbohydrate antigen 153, CA72-4: Gastric cancer biomarker CA72-4, CEA: Carcinoembryonic antigen, CRP: C-reactive protein, cTnI: cardiac troponin I, CYFRA21-1: Cytokeratin 19 fragment 21-1, FABP: human heart-type fatty-acid-binding protein, Gal-3: Galectin-3, GOx: Glucose Oxidase, GQdots: Graphene quantum dots, HBsAg: Hepatitis B surface antigen, HER2: Human epidermal growth factor receptor 2, hMMP9: human matrix metallopeptidase-9, IL-6: Human interleukin-6, MB: Methylene blue, MSNP: Mesoporous silica nanoparticles, Mtb: Mycobacterium tuberculosis antigen, MWCNT: Multi-walled carbon nanotubes, NC: Nanocellulose, NDs: nanodendrites, NPs: nanoparticles, NSs: nanosheets, NT-pro BNP: N-terminal prohormone of brain natriuretic peptide, PAMAM: Polyamidoamine, PCT: Procalcitonin, PDA: Polydopamine, PDC: Poly(L-DOPA), PDGF: Platelet-derived growth factor BB, PPy: Polypyrrole, PT: Potentiometry, PS: Polystyrene, PSA: Prostate-specific antigen, S100ß: S100 calcium-binding protein $\beta$, SW ASV: Square wave anodic stripping voltammetry, TCID50: 50\% tissue culture infective dose, Thi: Thionine.

\subsection{MNPs and Qdots as Nanocarriers}

MNPs and Qdots are excellent candidates to be used as nanocarriers for antibodies together with numerous electroactive substances [73,107] and especially enzymes [77,78]. The involvement of nanocarriers in the design of electrochemical immunosensors provides significant amplification of the analytical signal by handling an increased number of carried molecules close to the electrode surface. Numerous possible MNPs and Qdots surfaces containing functional groups permit various single molecule immobilization scenarios facilitating the design of the immunosensor. MNPs possess good electron transfer properties [108] and if used as nanocarriers can improve or provide direct electron transfer between the active site of the immobilized enzyme and the electrode.

If at first scientists used various nanostructures as carriers separately, now the usage of different types of nanomaterials together while trying to find the optimal combination for signal amplification prevails. One of the possible benefits is an increase in the loading capacity due to the increase in surface area for single molecule immobilization provided by nanocarriers. The deposition of graphene quantum dots (GQdots) on the surface of $\mathrm{Fe}_{3} \mathrm{O}_{4} / \mathrm{Ag}$ core-shell nanostructures allows an increase in the antibody loading capacity 
for the detection of Mycobacterium tuberculosis antigen [80]. GQdots were also used for nanocarrier design together with multiwalled carbon nanotubes (MWCNTs) [109,110]. Moreover, the enhancement of electron transfer can be achieved. The usage of $\mathrm{Au} / \mathrm{Pt}$ nanorods loaded with $\mathrm{MoSe}_{2}$ nanosheets enhances the electron transfer capability from the label to the electrode, resulting in the increase in the analytical signal intended for monitoring alpha fetoprotein (AFP) concentration [88].

A joint use of AuNPs and mesoporous silica nanoparticles (MSNPs) allows for the design of a controlled system of label release (Figure 5) [73]. The immunosensor was designed for the detection of PSA. For this purpose, the electroactive substance thionine was encapsulated in the MSNPs' pores, which were capped with AuNPs. After the formation of an immune complex between detection antibodies conjugated with AuNPs-MSNPs and analyte solution, the $\mathrm{pH}$ was lowered to 3.5 . Under acidic conditions, the hydrolysis of acid-labile acetal linker liberates AuNPs, resulting in the controlled release of thionine molecules, which were detected using DPV.

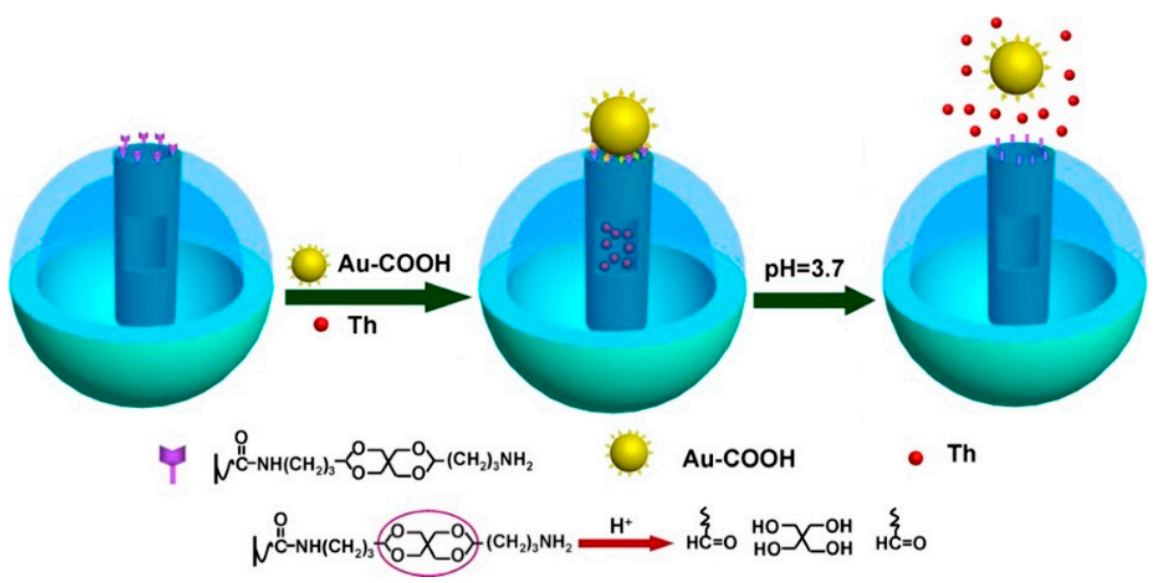

Figure 5. Schematic representation of $\mathrm{pH}$ controlled release of thionine for monitoring of PSA concentration using sandwich format immunosensor. Adapted from [73] with permission from Elsevier.

Metal-based nanoparticles can also act as a transport medium aimed to enhance electrochemical immunosensor response and stability or to capture the analyte from the sample. The aim usually is to concentrate the signal producing molecules towards the electrode to improve the detected analytical signal, and for this reason some immunosensor component is labeled using nanomaterials, usually the capture antibody $[79,100]$. The most common nanomaterials for this use case are magnetic nanoparticles, such as $\mathrm{Fe}_{3} \mathrm{O}_{4}$, where a strong magnet is placed near the electrode or other types of magnetic electrodes are used to draw antibodies with magnetic nanoparticle labels towards the electrode [100]. Magnetic nanoparticles are usually bimetallic with a magnetic core and a noble metal or polymer shell $[79,100]$. The use of magnetic labels with magnetic electrodes allows for increased antibody density near the electrode, which in turn leads to a higher density of signal producing molecules. In addition to signal enhancement, magnetic labels also act as substrates that can be easily removed from the electrode by removing the magnetic field, allowing for simple reuse of the electrode surface. Furthermore, magnetic labels improve and shorten immunosensing procedures by simplifying antibody washing and collection steps. Examples of such systems are provided for N-terminal prohormone of brain natriuretic peptide [100] and carcinoembryonic antigen detection [79]. In both cases, $\mathrm{Fe}_{3} \mathrm{O}_{4} @ \mathrm{PPy}-\mathrm{Au}$ and $\mathrm{Fe}_{3} \mathrm{O}_{4} @ \mathrm{Au}-\mathrm{Au}$ magnetic bimetallic nanoparticles were used, respectively, while the capture antibody was immobilized on the surface. Magnetic labels with capture antibodies can also be used to extract and concentrate the analyte from the sample solution. Soelberg et al. used magnetic nanoparticles with immobilized monoclonal antibodies to capture the staphylococcal enterotoxin B from a sample and then used a magnet to extract and concentrate the analyte [111]. Although the authors used an optical 
detection method, in principle, electrochemical detection could be performed by using the described analyte concentration method in conjunction with magnetic electrodes.

\subsection{MNPs and Qdots as Electroactive Labels in Electrochemical Immunosensors}

The action of an electrochemical immunosensor implies the presence of an electroactive substance whose concentration should be proportional to the concentration of the analyte. One of the feasible strategies of immunosensor design is based on the involvement of electroactive labels. This role can be played excellently by MNPs and Qdots. Such a strategy typically leads to the usage of sandwich immunoassay formats, although applications of the competitive electrochemical immunoassay format can also be found in the literature [89]. Moreover, a further enhancement of signal amplification already provided by electroactive labels can be achieved by the additional involvement of other nanostructures such as carbon nanomaterials $[90,91]$, metal oxides [92], etc., that serve the role of nanocarriers. High loading capacity caused by their large surface area allows the deposition of a higher amount of electroactive labels to the electrode, amplifying the analytical signal. In addition, MNPs and Qdots do not have specific limitations such as loss of activity and operational stability, which are inherent for popular biological labels-enzymes.

MNPs are composed of hundreds or even millions of atoms, which can be electrochemically oxidized. The monitoring of electrochemical oxidation is the most often applied operating principle of electrochemical immunosensors containing MNPs as labels, while AuNPs are one of the most commonly used. AuNPs, as well as the majority of other MNPs, possess good stability. As a result, the application of a high potential is necessary for AuNPs' electrooxidation, which leads to decreased sensitivity due to high background level [112]. Such a limitation is bypassed by a two-step process (Figure 6A). The first step includes the formation of $\mathrm{AuCl}_{4}{ }^{-}$ions from AuNPs to the solution, while various voltammetry types such as DPV, ASV and LSV are used for the detection of $\mathrm{Au}^{0}$ atom formation caused by the reduction during the second step. Metal ions can be released to the solution due to the dissolution in $\mathrm{HBr} / \mathrm{Br}_{2}$ mixture [113]. However, the toxicity of $\mathrm{HBr} / \mathrm{Br}_{2}$ solution limits the application of this method [114]. It was shown that diluted $30 \%$ aqua regia could be an alternative and provides the same detection level of the heart failure biomarker galectin-3 [93]. This solvent change provides a well-shaped anodic Au-stripping peak, which is not affected by the oxidation process of bromine [94]. However, the most common method of AuNP oxidation is electrochemical oxidation in $\mathrm{HCl}$ solution. Electrochemical oxidation at $+1.2+1.4 \mathrm{~V}$ is performed for no longer than $3 \mathrm{~min}$. The reduction of formed $\mathrm{AuCl}_{4}{ }^{-}$ions to $\mathrm{Au}^{0}$ is monitored by voltammetry during the second step [115]. Applying the $\mathrm{NaNO}_{3} / \mathrm{NaCl}$ mixture instead of $\mathrm{HCl}$ as a more ecofriendly oxidant provides a comparable immunosensor response to human matrix metallopeptidase 9 [81]. Such a detection strategy enables performing the detection of biomarkers at the $\mathrm{fg} \cdot \mathrm{mL}^{-1}$ concentration levels for human immunoglobulin G or human PSA [95].

Silver nanoparticles (AgNPs) are also quite popular labels for electrochemical immunosensors. The oxidation of AgNPs is performed at a noticeably lower potential in comparison with AuNPs, wherein the lower background signal is achieved by controlling the Ag deposition on the surface of the electrode [116,117]. As an alternative, permanganate or sodium hypochlorite can be used for the peroxidation of AgNPs [118]. Moreover, the detection of AgNPs can be performed in $\mathrm{KCl}$ solution through the monitoring of the solid-state $\mathrm{Ag} / \mathrm{AgCl}$ process. $\mathrm{Ag}^{+}$ions oxidized from $\mathrm{AgNPs}$ during the anodic potential scan form solid $\mathrm{AgCl}$, which reduces to $\mathrm{Ag}^{0}$ and $\mathrm{Cl}^{-}$ions during the cathodic potential scan. The return to the anodic part of the scan is accompanied with the reoxidation of metallic $\mathrm{Ag}$ to $\mathrm{AgCl}$. This experiment design allows the detection of AgNP labels without the peroxidation-dissolving step and reaches the $\mathrm{fg} \cdot \mathrm{mL}^{-1}$ detection level of PSA $[119,120]$.

Metal deposition on MNP labels can also be used for signal amplification (Figure 6B). The metal is deposited on the surface of MNPs, where MNPs act as nucleation sites [121]. After the deposition, the amount of deposited metal is quantified by the stripping potential. The susceptibility of Ag to oxidation makes it a perfect candidate for this purpose, wherein 
the most common formation of bimetallic $\mathrm{Au} / \mathrm{Ag}$ particles is used [96]. Such particles formed using the seed-mediated growth approach are normally more electroactive, and the enlarged particles are located closer to the electrode. It is important to reiterate that Ag reduction demands lower potential. Additional enhancement of the analytical signal can be reached by the enlargement of AuNP labels and by the optimization of AuNP shapes [97]. $\mathrm{Au} / \mathrm{Ag}$ bimetallic particles [98,99] as well as other MNPs [122] can be used as electron migration enhancers and mediate the redox response of the electroactive molecules.

A

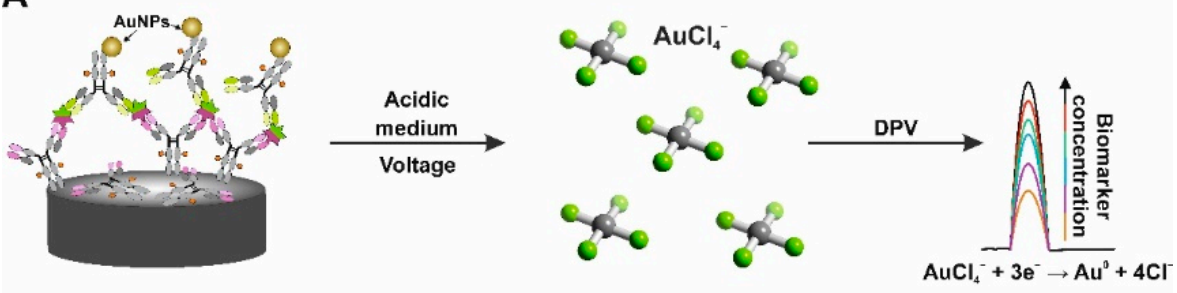

B
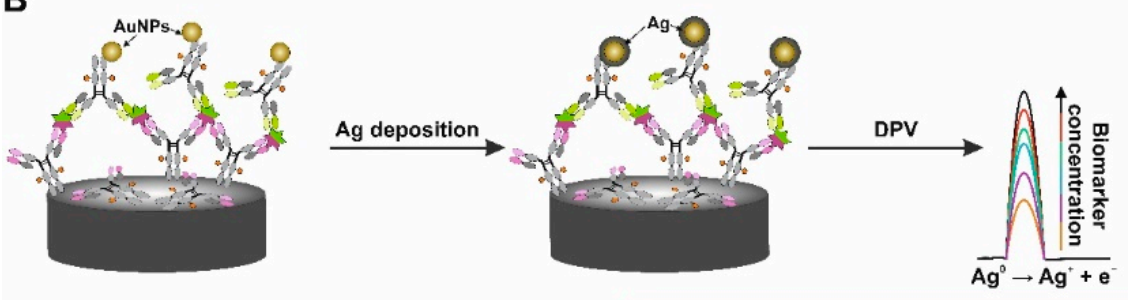

C
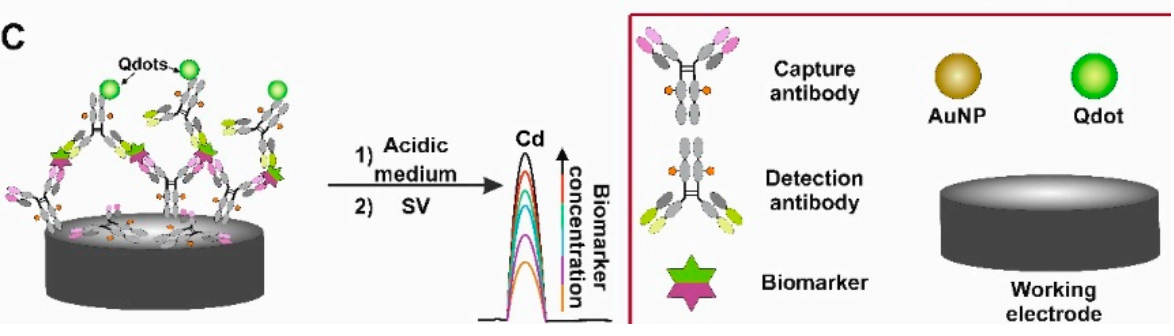

Figure 6. Schematic representation of sandwich format electrochemical immunosensor based on AuNP and Qdot labels. (A) Electrochemical oxidation of AuNPs in acidic medium. (B) Deposition of $\mathrm{Ag}$ on AuNPs. (C) Electrochemical oxidation of Qdots in acidic medium.

The metal dissolution approach in acidic medium such as $\mathrm{HCl}$ or $\mathrm{HNO}_{3}$ solutions with the further monitoring of released metal ion concentration can also be effectively utilized with Qdots labels (Figure 6C), which as well as MNPs are typically used in sandwich format immunoassay [123]. Qdots typically have a core-shell structure and consist of heavy metals such as $\mathrm{Cd}, \mathrm{Pb}$, and $\mathrm{Zn}$, which can be released from Qdots and quantified by sweeping the potential of the electrode. Such an approach allows the measurement of the concentration at the $\mathrm{pg} \cdot \mathrm{mL}^{-1}$ level for different biomarkers such as PSA, HE4 and HER2 [84,85,124]. Qdots are also suitable for the application as labels in electrochemical immunosensors aimed at microorganism detection (for instance, Escherichia coli [125]). However, the primary benefit of Qdots is the difference in oxidation potential allowing Qdots to be applied for multiplexed simultaneous detection of biomarkers. Heavy metal oxidation peaks are quite narrow, whereby the cross talk issue is less prevalent $[126,127]$. The oxidation potentials of the commonly used MNPs (based on $\mathrm{Ag}, \mathrm{Au}, \mathrm{Cu}$ ), in contrast, are located close to each other, which leads to a possible cross talk. This issue can be solved using electrochemical systems with multiple working electrodes, permitting spatial separation and ensuring multiplex biomarkers detection.

The design of photoelectrochemical immunosensors commonly implies the deposition of Qdots on the surface of the electrode. Enzymes can be involved as labels and are conjugated with detection antibodies. The generation of the analytical signal in these instances can be based on the interaction of immobilized Qdots with chemical and biological 
molecules, such as $\mathrm{O}_{2}$ and $\mathrm{H}_{2} \mathrm{O}_{2}$, which can be a substrate or a product for enzymatic reaction. Moreover, the principle of an immunosensor can be based on steric hindrance arising from immunocomplex formation, resulting in a reduced redox probe diffusion towards the Qdots [65]. Furthermore, Qdots can also be applied as labels in photoelectrochemical immunosensors. For instance, "signal off" sandwich type immunoassay for the detection of CEA at pg. $\mathrm{mL}^{-1}$ level was proposed by Fan et al. [128]. The operating principle was based on the immunorecognition event between CEA and the detection antibody. The decrease in the analytical signal was proportional to the concentration of the Qdot-antibody conjugate. This can be explained by the competitive absorption of photons and the consumption of electron donors performed by Qdots while accompanied by reduced electron transfer. The competitive immunoassay format can also be adapted for Qdots photochemical immunosensors [87]. Another interesting detection strategy is based on the involvement of noble metal nanoparticles as labels. Such nanoparticles possess high extinction coefficient and a wide absorption spectrum, which allows the design of immunosensors based on energy transfer from nanoparticles to Qdots and/or on steric hindrance $[129,130]$.

\subsection{MNPs as Catalytically Active Labels}

Metal-based nanomaterial labels can also be used as catalysts that facilitate reactions or even mimic enzymes. Electrochemical immunosensors employing this type of labeling strive to use MNPs to initiate chemical reactions that would otherwise not occur or to increase chemical reaction rates, in turn, enhancing registered electrical signals or shortening the analysis time. Noble metal nanoparticles are most commonly used for this type of electrochemical immunosensors since noble metals are stable, biocompatible, and exhibit strong catalytic activity as well as high electrical conductivity. Bimetallic nanomaterials are also used, usually consisting of a magnetic or noble metal core with a shell made from noble metals. The use of catalytically active nanomaterial tags replaces the need for traditional enzymatic labels, providing multiple advantages such as high surface area, reduced cost, immunosensor design complexity, compatibility with biomolecules, longer sensor shelf life, and improved reproducibility and repeatability $[104,131,132]$. Additionally, catalytically active nanomaterials are significantly easier to obtain compared with biomolecules such as enzymes. Finally, it is possible to select for desired physical, chemical, and catalytic properties by varying nanomaterial size/composition.

The most common subtype of these electrochemical immunosensors employ nanoparticles to directly catalyze $\mathrm{H}_{2} \mathrm{O}_{2}$ reduction [104,131,132], replacing the use of enzymes such as catalase [133] or HRP [134,135]. Typically, $\mathrm{H}_{2} \mathrm{O}_{2}$ is added to the sandwich immunoassay format immunosensor where the detection antibody is labeled with nanomaterials that catalyze $\mathrm{H}_{2} \mathrm{O}_{2}$ reduction. Usually, the current produced during $\mathrm{H}_{2} \mathrm{O}_{2}$ reaction is measured as an analytical signal. Several factors should be taken into consideration when designing these types of electrochemical immunosensors. Firstly, the highest nanomaterial electroactive surface area should be pursued so as to not hinder the reaction that is being catalyzed on the nanomaterial surface. As such, the step of antibody immobilization onto the nanoparticle plays a significant role. Secondly, high electrical conductivity of the material is desired in order to facilitate faster electron transfer kinetics. Lastly, the catalytic activity of the material should be taken into consideration. Many different materials are employed in immunosensor design for the purpose of $\mathrm{H}_{2} \mathrm{O}_{2}$ reduction catalysis; however, the most common are $\mathrm{Pt}$ and $\mathrm{Pd}$. A comprehensive comparative study of immunosensors with different nanomaterials is difficult to attain since changing the nanomaterial usually results in nanoparticles of different sizes and shapes, rendering a comparison difficult. For example, Guo et al. [131] presented an electrochemical immunosensor based on the catalysis of $\mathrm{H}_{2} \mathrm{O}_{2}$ reduction for CA125 detection. The authors presented the comparison of an analytical signal with three different labels_-gold, palladium, and bimetallic Au@Pd nanoparticles-modified with immobilized detection antibody. The results showed that the $\mathrm{Au}$-antibody label produced almost no response; $\mathrm{Pd}-\mathrm{Ab}$ facilitated a much larger current 
response, while the Au@Pd-antibody label displayed the highest current change. However, it is difficult to assess whether the signal enhancement was solely due to catalytic improvements since nanoparticles were of different sizes and antibody immobilization efficiency or electroactive surface area measurements were not presented for Au-antibody and Pd-antibody labels. Pourbaix diagrams can be employed as an aid for selecting the material to be used for nanoparticle labels [136]. Nonetheless, the replacement of traditional enzyme labels such as HRP $[134,135]$ with catalytic nanomaterial tags can lead to significant sensitivity improvements, resulting in a 2000 times lower LOD for CA125 detection. Other examples of catalytic $\mathrm{H}_{2} \mathrm{O}_{2}$ reduction-based electrochemical immunosensors for the detection of AFP [104,132] also exhibit similar sensitivity and LOD improvements compared to enzymatic labels [137,138].

Furthermore, various catalytic labels can be combined to further increase analytical signals. For example, Yang et al. reported an electrochemical immunosensor for hepatitis B surface antigen detection where detection antibodies were labeled with nanostructures consisting of amino-functionalized molybdenum dioxide nanosheets, Au@Pd nanostructures (Figure 7) [105]. The analytical signal enhancement can be attributed to higher surface area and improved electron transfer kinetics.

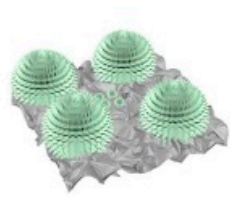

$\mathrm{Au} @ \mathrm{Pd} \mathrm{NDs} / \mathrm{MoO}_{2} \mathrm{NSs}$
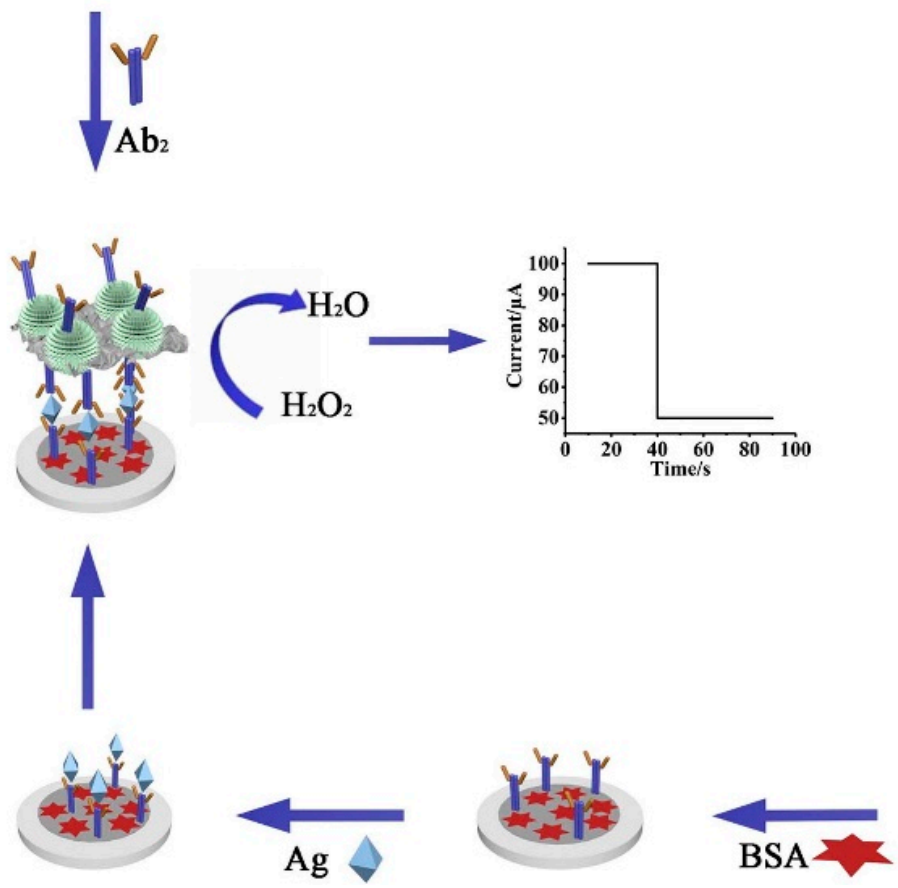

$\mathrm{MoO}_{2} \mathrm{NSs}$
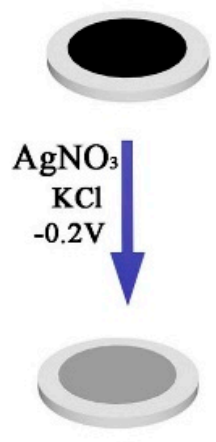

$\mathrm{Ab}_{1}$
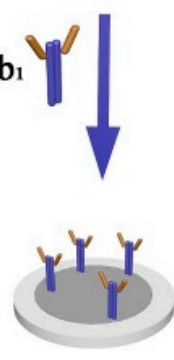

Figure 7. Schematic representation of the sandwich-type electrochemical immunosensor based on $\mathrm{Au} @ \mathrm{Pd}$ nanodendrite functionalized $\mathrm{MoO}_{2}$ nanosheet for the detection of $\mathrm{HBs} A g$. Adapted from [105] with permission from Elsevier.

\section{Conclusions}

Immunosensors based on different signal transducers can be used for biomarker detection. Among them, electrochemical immunosensors are increasingly used in clinical analysis and are becoming a promising alternative to existing laboratory methods. Electrochemical immunosensors possess unique properties such as high sensitivity, simplicity of fabrication, low cost, and applicability to perform the analysis of opaque and optically 
dense samples. However, the analytical parameters of electrochemical immunosensors can be improved using nanomaterials in their development. Zero-dimensional MNPs and Qdots were selected for this review due to their unique properties. MNPs (single metal or bimetallic) can be easily synthesized in various sizes. MNPs are chemically stable and possess a large surface-to-volume ratio. The availability of various modification methods enhances the ability of biomolecule immobilization. Therefore, MNPs and Qdots have found wide practical application, including as a tag for the immunosensor signal amplification. Qdots are commonly used in optical analytical systems; however, the application in electrochemical sensors is insufficiently studied. In this review, different strategies for electrochemical signal amplification using MNPs and Qdots as tags are discussed. Even though this review focused mainly on the single biomarker assays, MNPs and Qdots are also very promising nanomaterials for the design of electrochemical immunosensors intended for the simultaneous detection of multiple biomarkers.

Author Contributions: Conceptualization, A.P., B.B., A.K.-M. and A.R.; writing-original draft preparation, A.P., B.B., A.K.-M., A.R.; writing-review and editing, A.P., B.B., A.K.-M., A.R.; supervision A.K.-M. and A.R.; project administration, A.P.; funding acquisition, A.P. All authors have read and agreed to the published version of the manuscript.

Funding: This project has received funding from the European Social Fund (project no. 09.3.3-LMTK-712-19-0170) under grant agreement with the Research Council of Lithuania (LMTLT).

Institutional Review Board Statement: Not applicable.

Informed Consent Statement: Not applicable.

Data Availability Statement: Not applicable.

Conflicts of Interest: The authors declare no conflict of interest.

\section{References}

1. Yalow, R.S.; Berson, S.A. Immunoassay of endogenous plasma insulin in man. J. Clin. Investig. 1960, 39, 1157-1175. [CrossRef] [PubMed]

2. Nakane, P.K.; Pierce, G.B. Enzyme-labeled antibodies: Preparation and application for the localization of antigens. J. Histochem. Cytochem. 1966, 14, 929-931. [CrossRef] [PubMed]

3. Evtugyn, G.; Hianik, T. Electrochemical immuno- and aptasensors for mycotoxin determination. Chemosensors 2019, 7, 10. [CrossRef]

4. Engvall, E.; Perlmann, P. Enzyme-linked immunosorbent assay (ELISA) quantitative assay of immunoglobulin G. Immunochemistry 1971, 8, 871-874. [CrossRef]

5. Van Weemen, B.K.; Schuurs, A.H.W.M. Immunoassay using antigen-enzyme conjugates. FEBS Lett. 1971, 15, 232-236. [CrossRef]

6. Mollarasouli, F.; Kurbanoglu, S.; Ozkan, S.A. The Role of Electrochemical Immunosensors in Clinical Analysis. Biosensors 2019 , 9, 86. [CrossRef]

7. Ramanavicius, A.; Oztekin, Y.; Ramanaviciene, A. Electrochemical formation of polypyrrole-based layer for immunosensor design. Sens. Actuators B Chem. 2014, 197. [CrossRef]

8. Duffy, G.F.; Moore, E.J. Electrochemical Immunosensors for Food Analysis: A Review of Recent Developments. Anal. Lett. 2017, 50, 1-32. [CrossRef]

9. Pollap, A.; Kochana, J. Electrochemical Immunosensors for Antibiotic Detection. Biosensors 2019, 9, 61. [CrossRef] [PubMed]

10. Cho, I.-H.; Lee, J.; Kim, J.; Kang, M.-S.; Paik, J.K.; Ku, S.; Cho, H.-M.; Irudayaraj, J.; Kim, D.-H. Current Technologies of Electrochemical Immunosensors: Perspective on Signal Amplification. Sensors 2018, 18, 207. [CrossRef]

11. Makaraviciute, A.; Ramanaviciene, A. Site-directed antibody immobilization techniques for immunosensors. Biosens. Bioelectron. 2013, 50, 460-471. [CrossRef]

12. Baniukevic, J.; Kirlyte, J.; Ramanavicius, A.; Ramanaviciene, A. Application of oriented and random antibody immobilization methods in immunosensor design. Sens. Actuators B Chem. 2013, 189. [CrossRef]

13. Huang, H.; Zhu, J.-J. The electrochemical applications of quantum dots. Analyst 2013, 138, 5855-5865. [CrossRef]

14. Varghese, R.J.; Oluwafemi, O.S. The photoluminescence and biocompatibility of cuins2-based ternary quantum dots and their biological applications. Chemosensors 2020, 8, 101. [CrossRef]

15. WHO. Biomarkers in Risk Assessment: Validity and Validation; World Health Organization: Geneva, Switzerland, 2001.

16. Website for the National Cancer Institute (NCI), the U.S. Government's Principal Agency for Cancer Research. Available online: https:/ / www.cancer.gov / publications / dictionaries/cancer-terms/def/biomarker (accessed on 13 March 2021). 
17. Atkinson, A.J.; Colburn, W.A.; DeGruttola, V.G.; DeMets, D.L.; Downing, G.J.; Hoth, D.F.; Oates, J.A.; Peck, C.C.; Schooley, R.T.; Spilker, B.A.; et al. Biomarkers and surrogate endpoints: Preferred definitions and conceptual framework. Clin. Pharmacol. Ther. 2001, 69, 89-95.

18. Sherwani, S.I.; Khan, H.A.; Ekhzaimy, A.; Masood, A.; Sakharkar, M.K. Significance of HbA1c Test in Diagnosis and Prognosis of Diabetic Patients. Biomark. Insights 2016, 11, 95-104. [CrossRef]

19. Basu, N.N.; Ingham, S.; Hodson, J.; Lalloo, F.; Bulman, M.; Howell, A.; Evans, D.G. Risk of contralateral breast cancer in BRCA1 and BRCA2 mutation carriers: A 30-year semi-prospective analysis. Fam. Cancer 2015, 14, 531-538. [CrossRef] [PubMed]

20. Gundogdu, F.; Soylu, F.; Erkan, L.; Tatli, O.; Mavi, S.; Yavuzcan, A. The role of serum CA-125 levels and CA-125 tissue expression positivity in the prediction of the recurrence of stage III and IV epithelial ovarian tumors (CA-125 levels and tissue CA-125 in ovarian tumors). Arch. Gynecol. Obstet. 2011, 283, 1397-1402. [CrossRef] [PubMed]

21. Mitterhauser, M.; Wadsak, W. Imaging biomarkers or biomarker imaging? Pharmaceuticals 2014, 7, 765-778. [CrossRef]

22. Huss, R. Biomarkers. In Translational Regenerative Medicine; Atala, A., Allickson, J.G.B.T.-T.R.M., Eds.; Academic Press: Boston, MA, USA, 2015; pp. 235-241. ISBN 9780124104570.

23. Laterza, O.F.; Hendrickson, R.C.; Wagner, J.A. Molecular Biomarkers. Drug Inf. J. 2007, 41, 573-585. [CrossRef]

24. Darwish, I.A. Immunoassay Methods and their Applications in Pharmaceutical Analysis: Basic Methodology and Recent Advances. Int. J. Biomed. Sci. 2006, 2, 217-235.

25. Website for Bio-Rad Company. Available online: https://www.bio-rad-antibodies.com/elisa-types-direct-indirect-sandwichcompetition-elisa-formats.htm (accessed on 14 March 2021).

26. Kausaite-Minkstimiene, A.; Ramanaviciene, A.; Kirlyte, J.; Ramanavicius, A. Comparative study of random and oriented antibody immobilization techniques on the binding capacity of immunosensor. Anal. Chem. 2010, 82. [CrossRef]

27. Byzova, N.A.; Safenkova, I.V.; Slutskaya, E.S.; Zherdev, A.V.; Dzantiev, B.B. Less is More: A Comparison of Antibody-Gold Nanoparticle Conjugates of Different Ratios. Bioconjug. Chem. 2017, 28, 2737-2746. [CrossRef]

28. Mühlpfordt, H. The preparation of colloidal gold particles using tannic acid as an additional reducing agent. Experientia 1982, 38, 1127-1128. [CrossRef]

29. Correard, F.; Maximova, K.; Estève, M.-A.; Villard, C.; Roy, M.; Al-Kattan, A.; Sentis, M.; Gingras, M.; Kabashin, A.V.; Braguer, D. Gold nanoparticles prepared by laser ablation in aqueous biocompatible solutions: Assessment of safety and biological identity for nanomedicine applications. Int. J. Nanomed. 2014, 9, 5415-5430. [CrossRef]

30. Ruiz, G.; Tripathi, K.; Okyem, S.; Driskell, J.D. pH Impacts the Orientation of Antibody Adsorbed onto Gold Nanoparticles. Bioconjug. Chem. 2019, 30, 1182-1191. [CrossRef]

31. Makaraviciute, A.; Ruzgas, T.; Ramanavicius, A.; Ramanaviciene, A. Antibody fragment immobilization on planar gold and gold nanoparticle modified quartz crystal microbalance with dissipation sensor surfaces for immunosensor applications. Anal. Methods 2014, 6. [CrossRef]

32. Baniukevic, J.; Hakki Boyaci, I.; Goktug Bozkurt, A.; Tamer, U.; Ramanavicius, A.; Ramanaviciene, A. Magnetic gold nanoparticles in SERS-based sandwich immunoassay for antigen detection by well oriented antibodies. Biosens. Bioelectron. 2013, 43. [CrossRef]

33. Kaminiaris, M.D.; Mavrikou, S.; Georgiadou, M.; Paivana, G.; Tsitsigiannis, D.I.; Kintzios, S. An Impedance Based Electrochemical Immunosensor for Aflatoxin B1 Monitoring in Pistachio Matrices. Chemosensors 2020, 8, 121. [CrossRef]

34. Dvorakova, V.; Cadkova, M.; Datinska, V.; Kleparnik, K.; Foret, F.; Bilkova, Z.; Korecka, L. An advanced conjugation strategy for the preparation of quantum dot-antibody immunoprobes. Anal. Methods 2017, 9, 1991-1997. [CrossRef]

35. Sahoo, S.L.; Liu, C.-H.; Kumari, M.; Wu, W.-C.; Wang, C.-C. Biocompatible quantum dot-antibody conjugate for cell imaging, targeting and fluorometric immunoassay: Crosslinking, characterization and applications. RSC Adv. 2019, 9, 32791-32803. [CrossRef]

36. Thomas, J.A.; Schnell, F.; Kaveh-Baghbaderani, Y.; Berensmeier, S.; Schwaminger, S.P. Immunomagnetic Separation of Microorganisms with Iron Oxide Nanoparticles. Chemosensors 2020, 8, 17. [CrossRef]

37. Jampasa, S.; Siangproh, W.; Laocharoensuk, R.; Vilaivan, T.; Chailapakul, O. Electrochemical detection of c-reactive protein based on anthraquinone-labeled antibody using a screen-printed graphene electrode. Talanta 2018, 183, 311-319. [CrossRef] [PubMed]

38. Makaraviciute, A.; Ramanavicius, A.; Ramanaviciene, A. Development of a reusable protein G based SPR immunosensor for direct human growth hormone detection in real samples. Anal. Methods 2015, 7. [CrossRef]

39. Bodanszky, A.; Bodanszky, M. Sepharose-avidin column for the binding of biotin or biotin-containing peptides. Experientia 1970, 26, 327. [CrossRef] [PubMed]

40. Deng, L.; Kitova, E.N.; Klassen, J.S. Dissociation Kinetics of the Streptavidin-Biotin Interaction Measured Using Direct Electrospray Ionization Mass Spectrometry Analysis. J. Am. Soc. Mass Spectrom. 2013, 24, 49-56. [CrossRef]

41. Melnyk, O.; Duburcq, X.; Olivier, C.; Urbès, F.; Auriault, C.; Gras-Masse, H. Peptide Arrays for Highly Sensitive and Specific Antibody-Binding Fluorescence Assays. Bioconjug. Chem. 2002, 13, 713-720. [CrossRef] [PubMed]

42. Quash, G.; Roch, A.-M.; Niveleau, A.; Grange, J.; Keolouangkhot, T.; Huppert, J. The preparation of latex particles with covalently bound polyamines, IgG and measles agglutinins and their use in visual agglutination tests. J. Immunol. Methods 1978, 22, 165-174. [CrossRef]

43. Website for Thermo Fisher Scientific Company. Available online: https://www.thermofisher.com/order/catalog/product/S104 69\#/S10469 (accessed on 14 March 2021). 
44. Kondzior, M.; Grabowska, I. Antibody-Electroactive Probe Conjugates Based Electrochemical Immunosensors. Sensors 2020, 20 , 2014. [CrossRef] [PubMed]

45. Warsinke, A.; Benkert, A.; Scheller, F.W. Electrochemical immunoassays. Fresenius. J. Anal. Chem. 2000, 366, 622-634. [CrossRef]

46. Li, Y.; Zhang, Y.; Li, F.; Li, M.; Chen, L.; Dong, Y.; Wei, Q. Sandwich-type amperometric immunosensor using functionalized magnetic graphene loaded gold and silver core-shell nanocomposites for the detection of Carcinoembryonic antigen. J. Electroanal. Chem. 2017, 795, 1-9. [CrossRef]

47. Yan, Q.; Cao, L.; Dong, H.; Tan, Z.; Liu, Q.; Zhang, W.; Zhao, P.; Li, Y.; Liu, Y.; Dong, Y. Sensitive amperometric immunosensor with improved electrocatalytic Au@Pd urchin-shaped nanostructures for human epididymis specific protein 4 antigen detection. Anal. Chim. Acta 2019, 1069, 117-125. [CrossRef]

48. Thunkhamrak, C.; Reanpang, P.; Ounnunkad, K.; Jakmunee, J. Sequential injection system with amperometric immunosensor for sensitive determination of human immunoglobulin G. Talanta 2017, 171, 53-60. [CrossRef]

49. Shi, W.; Ma, Z. A novel label-free amperometric immunosensor for carcinoembryonic antigen based on redox membrane. Biosens. Bioelectron. 2011, 26, 3068-3071. [CrossRef]

50. Yang, Y.; Liu, Q.; Liu, Y.; Cui, J.; Liu, H.; Wang, P.; Li, Y.; Chen, L.; Zhao, Z.; Dong, Y. A novel label-free electrochemical immunosensor based on functionalized nitrogen-doped graphene quantum dots for carcinoembryonic antigen detection. Biosens. Bioelectron. 2017, 90, 31-38. [CrossRef] [PubMed]

51. Martínez-García, G.; Sánchez-Tirado, E.; González-Cortés, A.; Yáñez-Sedeño, P.; Pingarrón, J.M. Amperometric immunoassay for the obesity biomarker amylin using a screen printed carbon electrode functionalized with an electropolymerized carboxylated polypyrrole. Microchim. Acta 2018, 185, 323. [CrossRef]

52. Yáñez-Sedeño, P.; Campuzano, S.; Pingarrón, J.M. Multiplexed Electrochemical Immunosensors for Clinical Biomarkers. Sensors 2017, 17, 965. [CrossRef] [PubMed]

53. Mansuriya, B.D.; Altintas, Z. Graphene Quantum Dot-Based Electrochemical Immunosensors for Biomedical Applications. Materials 2019, 13, 96. [CrossRef] [PubMed]

54. Cui, F.; Zhou, Z.; Zhou, H.S. Review-Measurement and Analysis of Cancer Biomarkers Based on Electrochemical Biosensors. J. Electrochem. Soc. 2020, 167, 37525. [CrossRef]

55. Trindade, E.K.G.; Silva, B.V.M.; Dutra, R.F. A probeless and label-free electrochemical immunosensor for cystatin C detection based on ferrocene functionalized-graphene platform. Biosens. Bioelectron. 2019, 138, 111311. [CrossRef] [PubMed]

56. Zeng, Y.; Bao, J.; Zhao, Y.; Huo, D.; Chen, M.; Qi, Y.; Yang, M.; Fa, H.; Hou, C. A sandwich-type electrochemical immunoassay for ultrasensitive detection of non-small cell lung cancer biomarker CYFRA21-1. Bioelectrochemistry 2018, 120, 183-189. [CrossRef] [PubMed]

57. Sun, X.; Hui, N.; Luo, X. Reagentless and label-free voltammetric immunosensor for carcinoembryonic antigen based on polyaniline nanowires grown on porous conducting polymer composite. Microchim. Acta 2017, 184, 889-896. [CrossRef]

58. Feng, C.; Xu, Y.; Song, L. Study on highly sensitive potentiometric IgG immunosensor. Sens. Actuators B Chem. 2000, 66, 190-192. [CrossRef]

59. Tang, D.P.; Yuan, R.; Chai, Y.Q.; Zhong, X.; Liu, Y.; Dai, J.Y.; Zhang, L.Y. Novel potentiometric immunosensor for hepatitis B surface antigen using a gold nanoparticle-based biomolecular immobilization method. Anal. Biochem. 2004, 333, 345-350. [CrossRef]

60. Ibupoto, Z.H.; Jamal, N.; Khun, K.; Willander, M. Development of a disposable potentiometric antibody immobilized ZnO nanotubes based sensor for the detection of C-reactive protein. Sens. Actuators B Chem. 2012, 166-167, 809-814. [CrossRef]

61. Fowler, J.M.; Wong, D.K.Y.; Brian Halsall, H.; Heineman, W.R. Recent developments in electrochemical immunoassays and immunosensors. In Electrochemical Sensors, Biosensors and their Biomedical Applications; Elsevier Inc.: Amsterdam, The Netherlands, 2008; pp. 115-143. ISBN 9780123737380.

62. Cao, Y.; Zheng, M.; Cai, W.; Wang, Z. Enzyme-loaded liposome with biocatalytic precipitation for potentiometric immunoassay of thyroid-stimulating hormone in thyroid carcinoma. Chinese Chem. Lett. 2020, 31, 463-467. [CrossRef]

63. Lv, S.; Lin, Z.; Zhang, K.; Lu, M.; Tang, D. Polyion oligonucleotide-decorated gold nanoparticles with tunable surface charge density for amplified signal output of potentiometric immunosensor. Anal. Chim. Acta 2017, 964, 67-73. [CrossRef]

64. Thürer, R.; Vigassy, T.; Hirayama, M.; Wang, J.; Bakker, E.; Pretsch, E. Potentiometric immunoassay with quantum dot labels. Anal. Chem. 2007, 79, 5107-5110. [CrossRef]

65. Shu, J.; Tang, D. Current Advances in Quantum-Dots-Based Photoelectrochemical Immunoassays. Chem. Asian J. 2017, 12, 2780-2789. [CrossRef]

66. Li, R.; Gao, J.; Gao, P.; Zhang, S.; Liu, Y.; Du, B.; Wei, Q. A sensitive photoelectrochemical immunoassay based on mesoporous carbon/core-shell quantum dots as donor-acceptor light-harvesting architectures. New J. Chem. 2015, 39, 731-738. [CrossRef]

67. Liang, M.; Liu, S.; Wei, M.; Guo, L.-H. Photoelectrochemical Oxidation of DNA by Ruthenium Tris(bipyridine) on a Tin Oxide Nanoparticle Electrode. Anal. Chem. 2006, 78, 621-623. [CrossRef] [PubMed]

68. Zhao, W.-W.; Xu, J.-J.; Chen, H.-Y. Photoelectrochemical bioanalysis: The state of the art. Chem. Soc. Rev. 2015, 44, 729-741. [CrossRef] [PubMed]

69. Chen, J.; Zhao, G.-C. A novel signal-on photoelectrochemical immunosensor for detection of alpha-fetoprotein by in situ releasing electron donor. Biosens. Bioelectron. 2017, 98, 155-160. [CrossRef] 
70. Tabrizi, M.A.; Ferré-Borrull, J.; Kapruwan, P.; Marsal, L.F. A photoelectrochemical sandwich immunoassay for protein S100 $\beta$, a biomarker for Alzheimer's disease, using an ITO electrode modified with a reduced graphene oxide-gold conjugate and CdS-labeled secondary antibody. Microchim. Acta 2019, 186, 117. [CrossRef] [PubMed]

71. Zhang, N.; Wang, Y.; Zhao, G.; Wang, C.; Li, Y.; Zhang, Y.; Wang, H.; Wei, Q. A photoelectrochemical immunosensor based on $\mathrm{CdS} / \mathrm{CdTe}$-cosensitized $\mathrm{SnO} 2$ as a platform for the ultrasensitive detection of amyloid $\beta$-protein. Analyst 2020, 145, 619-625. [CrossRef]

72. Sun, X.; Li, C.; Zhu, Q.; Chen, J.; Li, J.; Ding, H.; Sang, F.; Kong, L.; Chen, Z.; Wei, Q. A novel ultrasensitive sandwichtype photoelectrochemical immunoassay for PSA detection based on dual inhibition effect of Au/MWCNTs nanohybrids on N-GQDs/CdS QDs dual sensitized urchin-like TiO2. Electrochim. Acta 2020, 333, 135480. [CrossRef]

73. Fan, D.; Li, N.; Ma, H.; Li, Y.; Hu, L.; Du, B.; Wei, Q. Electrochemical immunosensor for detection of prostate specific antigen based on an acid cleavable linker into MSN-based controlled release system. Biosens. Bioelectron. 2016, 85, 580-586. [CrossRef]

74. Ma, N.; Zhang, T.; Yan, T.; Kuang, X.; Wang, H.; Wu, D.; Wei, Q. Novel electrochemical immunosensor for sensitive monitoring of cardiac troponin I using antigen-response cargo released from mesoporous Fe3O4. Biosens. Bioelectron. 2019, 143, 111608. [CrossRef]

75. Song, D.; Zheng, J.; Myung, N.V.; Xu, J.; Zhang, M. Sandwich-type electrochemical immunosensor for CEA detection using magnetic hollow Ni/C@SiO2 nanomatrix and boronic acid functionalized CPS@PANI@Au probe. Talanta 2021, 225, 122006. [CrossRef]

76. Kumar, N.; Sharma, S.; Nara, S. Dual gold nanostructure-based electrochemical immunosensor for CA125 detection. Appl. Nanosci. 2018, 8, 1843-1853. [CrossRef]

77. Liu, C.; Dong, J.; Waterhouse, G.I.N.; Cheng, Z.; Ai, S. Electrochemical immunosensor with nanocellulose-Au composite assisted multiple signal amplification for detection of avian leukosis virus subgroup J. Biosens. Bioelectron. 2018, 101, 110-115. [CrossRef] [PubMed]

78. Wang, H.; Li, X.; Mao, K.; Li, Y.; Du, B.; Zhang, Y.; Wei, Q. Electrochemical immunosensor for $\alpha$-fetoprotein detection using ferroferric oxide and horseradish peroxidase as signal amplification labels. Anal. Biochem. 2014, 465, 121-126. [CrossRef] [PubMed]

79. Li, J.; Gao, H.; Chen, Z.; Wei, X.; Yang, C.F. An electrochemical immunosensor for carcinoembryonic antigen enhanced by self-assembled nanogold coatings on magnetic particles. Anal. Chim. Acta 2010, 665, 98-104. [CrossRef]

80. Tufa, L.T.; Oh, S.; Tran, V.T.; Kim, J.; Jeong, K.J.; Park, T.J.; Kim, H.J.; Lee, J. Electrochemical immunosensor using nanotriplex of graphene quantum dots, $\mathrm{Fe}_{3} \mathrm{O}_{4}$ and $\mathrm{Ag}$ nanoparticles for tuberculosis. Electrochim. Acta 2018, 290, 369-377. [CrossRef]

81. López-Marzo, A.M.; Hoyos-De-La-Torre, R.; Baldrich, E. NaNO3/NaCl Oxidant and Polyethylene Glycol (PEG) Capped Gold Nanoparticles (AuNPs) as a Novel Green Route for AuNPs Detection in Electrochemical Biosensors. Anal. Chem. 2018, 90, 4010-4018. [CrossRef] [PubMed]

82. Zhang, S.; Ma, H.; Yan, L.; Cao, W.; Yan, T.; Wei, Q.; Du, B. Copper-doped titanium dioxide nanoparticles as dual-functional labels for fabrication of electrochemical immunosensors. Biosens. Bioelectron. 2014, 59, 335-341. [CrossRef]

83. Feng, L.N.; Bian, Z.P.; Peng, J.; Jiang, F.; Yang, G.H.; Zhu, Y.D.; Yang, D.; Jiang, L.P.; Zhu, J.J. Ultrasensitive multianalyte electrochemical immunoassay based on metal ion functionalized titanium phosphate nanospheres. Anal. Chem. 2012, 84, 7810-7815. [CrossRef]

84. Lah, Z.M.A.N.H.; Ahmad, S.A.A.; Zaini, M.S.; Kamarudin, M.A. An Electrochemical Sandwich Immunosensor for the Detection of HER2 using Antibody-Conjugated PbS Quantum Dot as a label. J. Pharm. Biomed. Anal. 2019, 174, 608-617. [CrossRef]

85. Ehzari, H.; Amiri, M.; Safari, M. Enzyme-free sandwich-type electrochemical immunosensor for highly sensitive prostate specific antigen based on conjugation of quantum dots and antibody on surface of modified glassy carbon electrode with core-shell magnetic metal-organic frameworks. Talanta 2020, 210, 120641. [CrossRef]

86. Martín-Yerga, D.; González-García, M.B.; Costa-García, A. Electrochemical immunosensor for anti-tissue transglutaminase antibodies based on the in situ detection of quantum dots. Talanta 2014, 130, 598-602. [CrossRef] [PubMed]

87. Xu, R.; Jiang, Y.; Xia, L.; Zhang, T.; Xu, L.; Zhang, S.; Liu, D.; Song, H. A sensitive photoelectrochemical biosensor for AFP detection based on $\mathrm{ZnO}$ inverse opal electrodes with signal amplification of CdS-QDs. Biosens. Bioelectron. 2015, 74, 411-417. [CrossRef]

88. Zhang, S.; Zhang, C.; Jia, Y.; Zhang, X.; Dong, Y.; Li, X.; Liu, Q.; Li, Y.; Zhao, Z. Sandwich-type electrochemical immunosensor based on Au@Pt DNRs/NH 2 -MoSe 2 NSs nanocomposite as signal amplifiers for the sensitive detection of alpha-fetoprotein. Bioelectrochemistry 2019, 128, 140-147. [CrossRef]

89. Lou, Y.; He, T.; Jiang, F.; Shi, J.J.; Zhu, J.J. A competitive electrochemical immunosensor for the detection of human interleukin-6 based on the electrically heated carbon electrode and silver nanoparticles functionalized labels. Talanta 2014, 122, 135-139. [CrossRef]

90. Song, W.; Li, H.; Liu, H.; Wu, Z.; Qiang, W.; Xu, D. Fabrication of streptavidin functionalized silver nanoparticle decorated graphene and its application in disposable electrochemical sensor for immunoglobulin e. Electrochem. Commun. 2013, 31, 16-19. [CrossRef]

91. Chen, P.; Wang, T.; Zheng, X.; Tian, D.; Xia, F.; Zhou, C. An ultrasensitive electrochemical immunosensor based on C60-modified polyamidoamine dendrimers and Au NPs for co-catalytic silver deposition. New J. Chem. 2018, 42, 4653-4660. [CrossRef] 
92. Chen, S.; Yang, Y.; Li, W.; Song, Y.; Shi, L.; Hong, C. A sandwich-type electrochemical immunosensor using Ag@CeO2-Au as a lable for sensitive detection of carcinoembryonic antigen. Microchem. J. 2020, 159, 105415. [CrossRef]

93. Liu, H.; Cheng, Y.; Chen, Y.; Xiao, H.; Sui, Y.; Xie, Q.; Liu, R.; Yang, X. Dual-signal sandwich-type electrochemical immunoassay of galectin-3 using methylene blue and gold nanoparticles biolabels. J. Electroanal. Chem. 2020, 861, 113952. [CrossRef]

94. Sui, Y.; Xu, A.; Jin, X.; Zheng, J.; He, X.; Cheng, Y.; Xie, Q.; Liu, R. In situ enzymatic generation of gold for ultrasensitive amperometric sandwich immunoassay of procalcitonin. Biosens. Bioelectron. 2018, 117, 422-428. [CrossRef]

95. Qin, X.; Xu, A.; Liu, L.; Deng, W.; Chen, C.; Tan, Y.; Fu, Y.; Xie, Q.; Yao, S. Ultrasensitive electrochemical immunoassay of proteins based on in situ duple amplification of gold nanoparticle biolabel signals. Chem. Commun. 2015, 51, 8540-8543. [CrossRef]

96. Shamsipur, M.; Emami, M.; Farzin, L.; Saber, R. A sandwich-type electrochemical immunosensor based on in situ silver deposition for determination of serum level of HER2 in breast cancer patients. Biosens. Bioelectron. 2018, 103, 54-61. [CrossRef]

97. Duangkaew, P.; Wutikhun, T.; Laocharoensuk, R. Triple signal amplification strategy based on size and shape transformation of ultrasmall sub-10 nm gold nanoparticles tag towards sensitivity improvement of electrochemical immunosensors. Sens. Actuators B Chem. 2017, 239, 430-437. [CrossRef]

98. Wang, C.; Ding, L.; Qu, F. Sensitive electrochemical immunosensor for platelet-derived growth factor in serum with electron transfer mediated by gold nanoparticles initiated silver enhancement. Measurement 2013, 46, 279-283. [CrossRef]

99. Yang, G.; Lai, Y.; Xiao, Z.; Tang, C.; Deng, Y. Ultrasensitive electrochemical immunosensor of carcinoembryonic antigen based on gold-label silver-stain signal amplification. Chinese Chem. Lett. 2018, 29, 1857-1860. [CrossRef]

100. Li, Y.; Wang, Y.; Zhang, N.; Fan, D.; Liu, L.; Yan, T.; Yang, X.; Ding, C.; Wei, Q.; Ju, H. Magnetic electrode-based electrochemical immunosensor using amorphous bimetallic sulfides of CoSnSx as signal amplifier for the NTpro BNP detection. Biosens. Bioelectron. 2019, 131, 250-256. [CrossRef]

101. Tan, X.; Zhang, L.; Deng, X.; Miao, L.; Li, H.; Zheng, G. Redox active molybdophosphate produced by $\mathrm{Cu}_{3}\left(\mathrm{PO}_{4}\right)_{2}$ nanospheres for enhancing enzyme-free electrochemical immunoassay of C-reactive protein. New J. Chem. 2017, 41, 11867-11871. [CrossRef]

102. Wu, D.; Guo, Z.; Liu, Y.; Guo, A.; Lou, W.; Fan, D.; Wei, Q. Sandwich-type electrochemical immunosensor using dumbbell-like nanoparticles for the determination of gastric cancer biomarker CA72-4. Talanta 2015, 134, 305-309. [CrossRef]

103. Cui, Z.; Wu, D.; Zhang, Y.; Ma, H.; Li, H.; Du, B.; Wei, Q.; Ju, H. Ultrasensitive electrochemical immunosensors for multiplexed determination using mesoporous platinum nanoparticles as nonenzymatic labels. Anal. Chim. Acta 2014, 807, 44-50. [CrossRef] [PubMed]

104. Li, N.; Ma, H.; Cao, W.; Wu, D.; Yan, T.; Du, B.; Wei, Q. Highly sensitive electrochemical immunosensor for the detection of alpha fetoprotein based on PdNi nanoparticles and N-doped graphene nanoribbons. Biosens. Bioelectron. 2015, 74, 786-791. [CrossRef]

105. Yang, Q.; Wang, P.; Ma, E.; Yu, H.; Zhou, K.; Tang, C.; Ren, J.; Li, Y.; Liu, Q.; Dong, Y. A sandwich-type electrochemical immunosensor based on Au@Pd nanodendrite functionalized $\mathrm{MoO} 2$ nanosheet for highly sensitive detection of HBsAg. Bioelectrochemistry 2021, 138, 107713. [CrossRef]

106. Li, Y.; Tian, L.; Liu, L.; Khan, M.S.; Zhao, G.; Fan, D.; Cao, W.; Wei, Q. Dual-responsive electrochemical immunosensor for detection of insulin based on dual-functional zinc silicate spheres-palladium nanoparticles. Talanta 2018, 179, 420-425. [CrossRef]

107. Kang, J.; Li, Z.; Wang, G. A novel signal amplification strategy electrochemical immunosensor for ultra-sensitive determination of p53 protein. Bioelectrochemistry 2021, 137, 107647. [CrossRef]

108. Brasiunas, B.; Popov, A.; Ramanavicius, A.; Ramanaviciene, A. Gold nanoparticle based colorimetric sensing strategy for the determination of reducing sugars. Food Chem. 2021, 351, 129238. [CrossRef]

109. Serafín, V.; Valverde, A.; Martínez-García, G.; Martínez-Periñán, E.; Comba, F.; Garranzo-Asensio, M.; Barderas, R.; Yáñez-Sedeño, P.; Campuzano, S.; Pingarrón, J.M. Graphene quantum dots-functionalized multi-walled carbon nanotubes as nanocarriers in electrochemical immunosensing. Determination of IL-13 receptor A2 in colorectal cells and tumor tissues with different metastatic potential. Sens. Actuators B Chem. 2019, 284, 711-722. [CrossRef]

110. Serafín, V.; Valverde, A.; Garranzo-Asensio, M.; Barderas, R.; Campuzano, S.; Yáñez-Sedeño, P.; Pingarrón, J.M. Simultaneous amperometric immunosensing of the metastasis-related biomarkers IL-13R $\alpha 2$ and CDH-17 by using grafted screen-printed electrodes and a composite prepared from quantum dots and carbon nanotubes for signal amplification. Microchim. Acta 2019 [CrossRef]

111. Soelberg, S.D.; Stevens, R.C.; Limaye, A.P.; Furlong, C.E. Surface Plasmon Resonance Detection Using Antibody-Linked Magnetic Nanoparticles for Analyte Capture, Purification, Concentration, and Signal Amplification. Anal. Chem. 2009, 81, $2357-2363$. [CrossRef]

112. Lara, S.; Perez-Potti, A. Applications of Nanomaterials for Immunosensing. Biosensors 2018, 8, 104. [CrossRef]

113. Ozsoz, M.; Erdem, A.; Kerman, K.; Ozkan, D.; Tugrul, B.; Topcuoglu, N.; Ekren, H.; Taylan, M. Electrochemical Genosensor Based on Colloidal Gold Nanoparticles for the Detection of Factor V Leiden Mutation Using Disposable Pencil Graphite Electrodes. Anal. Chem. 2003, 75, 2181-2187. [CrossRef] [PubMed]

114. Rasheed, P.A.; Sandhyarani, N. Electrochemical DNA sensors based on the use of gold nanoparticles: A review on recent developments. Microchim. Acta 2017, 184, 981-1000. [CrossRef]

115. Kokkinos, C.; Economou, A.; Prodromidis, M.I. Electrochemical immunosensors: Critical survey of different architectures and transduction strategies. TrAC Trends Anal. Chem. 2016, 79, 88-105. [CrossRef]

116. Lim, S.A.; Ahmed, M.U. Electrochemical immunosensors and their recent nanomaterial-based signal amplification strategies: A review. RSC Adv. 2016, 6, 24995-25014. [CrossRef] 
117. Szymanski, M.; Porter, R.; Dep, G.V.; Wang, Y.; Haggett, B.G.D. Silver nanoparticles and magnetic beads with electrochemical measurement as a platform for immunosensing devices. Phys. Chem. Chem. Phys. 2011, 13, 5383-5387. [CrossRef]

118. Cunningham, J.C.; Scida, K.; Kogan, M.R.; Wang, B.; Ellington, A.D.; Crooks, R.M. Paper diagnostic device for quantitative electrochemical detection of ricin at picomolar levels. Lab Chip 2015, 15, 3707-3715. [CrossRef]

119. Ting, B.P.; Zhang, J.; Khan, M.; Yang, Y.Y.; Ying, J.Y. The solid-state Ag/AgCl process as a highly sensitive detection mechanism for an electrochemical immunosensor. Chem. Commun. 2009, 0, 6231-6233. [CrossRef]

120. Iglesias-Mayor, A.; Amor-Gutiérrez, O.; Costa-García, A.; de la Escosura-Muñiz, A. Nanoparticles as emerging labels in electrochemical immunosensors. Sensors 2019, 19, 5137. [CrossRef]

121. Ramanaviciene, A.; Voronovic, J.; Popov, A.; Drevinskas, R.; Kausaite-Minkstimiene, A.; Ramanavicius, A. Investigation of biocatalytic enlargement of gold nanoparticles using dynamic light scattering and atomic force microscopy. Colloids Surf. A Physicochem. Eng. Asp. 2016, 510, 183-189. [CrossRef]

122. Jiang, P.; Wang, Y.; Zhao, L.; Ji, C.; Chen, D.; Nie, L. Applications of gold nanoparticles in non-optical biosensors. Nanomaterials 2018, 8, 977. [CrossRef]

123. Prodromidis, M.I.; Economou, A. New Trends in Antibody-Based Electrochemical Biosensors. Compr. Anal. Chem. 2017, 77, 55-100. [CrossRef]

124. Cadkova, M.; Kovarova, A.; Dvorakova, V.; Metelka, R.; Bilkova, Z.; Korecka, L. Electrochemical quantum dots-based magnetoimmunoassay for detection of HE4 protein on metal film-modified screen-printed carbon electrodes. Talanta 2018, 182, 111-115. [CrossRef]

125. Zhong, M.; Yang, L.; Yang, H.; Cheng, C.; Deng, W.; Tan, Y.; Xie, Q.; Yao, S. An electrochemical immunobiosensor for ultrasensitive detection of Escherichia coli O157:H7 using CdS quantum dots-encapsulated metal-organic frameworks as signal-amplifying tags. Biosens. Bioelectron. 2019, 126, 493-500. [CrossRef]

126. Zupančič, U.; Rainbow, J.; Flynn, C.; Aidoo-Brown, J.; Estrela, P.; Moschou, D. Strategies for Multiplexed Electrochemical Sensor Development; Springer: Singapore, 2021; pp. 63-93.

127. Tang, D.; Hou, L.; Niessner, R.; Xu, M.; Gao, Z.; Knopp, D. Multiplexed electrochemical immunoassay of biomarkers using metal sulfide quantum dot nanolabels and trifunctionalized magnetic beads. Biosens. Bioelectron. 2013, 46, 37-43. [CrossRef]

128. Fan, G.C.; Zhu, H.; Du, D.; Zhang, J.R.; Zhu, J.J.; Lin, Y. Enhanced Photoelectrochemical Immunosensing Platform Based on CdSeTe@CdS:Mn Core-Shell Quantum Dots-Sensitized $\mathrm{TiO}_{2}$ Amplified by CuS Nanocrystals Conjugated Signal Antibodies. Anal. Chem. 2016, 88, 3392-3399. [CrossRef] [PubMed]

129. Zhao, W.W.; Wang, J.; Xu, J.J.; Chen, H.Y. Energy transfer between CdS quantum dots and Au nanoparticles in photoelectrochemical detection. Chem. Commun. 2011, 47, 10990-10992. [CrossRef]

130. Dong, Y.X.; Cao, J.T.; Liu, Y.M.; Ma, S.H. A novel immunosensing platform for highly sensitive prostate specific antigen detection based on dual-quenching of photocurrent from CdSe sensitized $\mathrm{TiO} 2$ electrode by gold nanoparticles decorated polydopamine nanospheres. Biosens. Bioelectron. 2017, 91, 246-252. [CrossRef] [PubMed]

131. Guo, A.; Wu, D.; Ma, H.; Zhang, Y.; Li, H.; Du, B.; Wei, Q. An ultrasensitive enzyme-free electrochemical immunosensor for CA125 using Au@Pd core-shell nanoparticles as labels and platforms for signal amplification. J. Mater. Chem. B 2013, 1, $4052-4058$. [CrossRef]

132. Zhao, L.; Li, S.; He, J.; Tian, G.; Wei, Q.; Li, H. Enzyme-free electrochemical immunosensor configured with Au-Pd nanocrystals and N-doped graphene sheets for sensitive detection of AFP. Biosens. Bioelectron. 2013, 49, 222-225. [CrossRef]

133. Dong, S.; Wang, S.; Gyimah, E.; Zhu, N.; Wang, K.; Wu, X.; Zhang, Z. A novel electrochemical immunosensor based on catalase functionalized AuNPs-loaded self-assembled polymer nanospheres for ultrasensitive detection of tetrabromobisphenol A bis(2-hydroxyethyl) ether. Anal. Chim. Acta 2019, 1048, 50-57. [CrossRef]

134. Wu, L.; Chen, J.; Du, D.; Ju, H. Electrochemical immunoassay for CA125 based on cellulose acetate stabilized antigen/colloidal gold nanoparticles membrane. Electrochim. Acta 2006, 51, 1208-1214. [CrossRef]

135. Wu, L.; Yan, F.; Ju, H. An amperometric immunosensor for separation-free immunoassay of CA125 based on its covalent immobilization coupled with thionine on carbon nanofiber. J. Immunol. Methods 2007, 322, 12-19. [CrossRef]

136. Gu, L.; Luo, N.; Miley, G.H. Cathode electrocatalyst selection and deposition for a direct borohydride/hydrogen peroxide fuel cell. J. Power Sources 2007, 173, 77-85. [CrossRef]

137. Yuan, Y.; Li, S.; Xue, Y.; Liang, J.; Cui, L.; Li, Q.; Zhou, S.; Huang, Y.; Li, G.; Zhao, Y. A Fe $\mathrm{O}_{4} @$ Au-basedpseudo-homogeneous electrochemical immunosensor for AFP measurement using AFP antibody-GNPs-HRP as detection probe. Anal. Biochem. 2017, 534, 56-63. [CrossRef]

138. Li, Y.; Yuan, R.; Chai, Y.; Zhuo, Y.; Su, H.; Zhang, Y. Horseradish peroxidase-loaded nanospheres attached to hollow gold nanoparticles as signal enhancers in an ultrasensitive immunoassay for alpha-fetoprotein. Microchim. Acta 2014, 181, 679-685. [CrossRef] 